\title{
HISTÓRIA DA CONSTRUÇÃO DA ARQUEOLOGIA HISTÓRICA BRASILEIRA
}

Maria Dulce Gaspar*

\section{Introdução}

AArqueologia Histórica brasileira é um campo de investigação fascinante que desvenda uma série de hábitos, costumes e mentalidades que se estabeleceram no que veio a ser o território brasileiro e países vizinhos com o início da colonização européia. Para apresentar a história de sua construção vou apoiar-me no balanço bibliográfico da disciplina elaborado por Andrade Lima (1993). Em seu levantamento, apresenta as primeiras intervenções arqueológicas em contextos derivados dos europeus e seus descendentes e mostra como o início da disciplina estava atrelado aos trabalhos de recuperação do patrimônio cultural brasileiro.

Como estratégia de abordagem do tema, vou correlacionar os desdobramentos da Arqueologia Histórica com a Arquitetura, a História sempre considerando-a como um desdobramento da Arqueologia Pré-Histórica. Terei como referência a análise sobre Arqueologia brasileira empreendida por Prous (1991) e a avaliação dos períodos mais recentes feita por Barreto (2000). Vou também estabelecer correlações com as principais correntes teóricas que nortearam as pesquisas na Europa e Estados Unidos e que influenciaram a construção da Arqueologia brasileira. Farei uma breve avaliação da Ecologia Cultural, do Neo-Evolucionismo, da Nova Arqueologia (ou Arqueologia Processual) e do Pós-Processualismo, sempre correlacionando com a Arqueologia Histórica.

\section{Breve histórico da Arqueologia}

É difícil estabelecer quando começou o interesse por objetos relacionados com o passado.

(*) Museu Nacional da Universidade Federal do Rio de Janeiro-UFRJ, Pesquisadora do CNPq e FAPERJ.
Coleções de antigüidade foram formadas desde o século VI antes da era Cristã. Nabónido, último rei da Babilônia, colecionou antiguidades e escavou em Ur, mas não é possível considerar que a arqueologia tenha surgido nesse momento (Daniel 1967). Foi necessária uma série de passos, acúmulo de saber, confluência de interesses, mudança de paradigma para formar a disciplina. Nesse processo, os viajantes, na era do antiquarismo, tiveram papel fundamental no que se refere ao acúmulo de informações que levaram a uma reflexão sobre o passado.

Luiz de Castro Faria (1989) fornece uma acurada leitura do início da disciplina que resumo e apresento. $\mathrm{O}$ antiquarismo foi a primeira expressão do que mais tarde seria conhecido como arqueologia clássica. No século XVI, os dilettanti já se extasiavam diante das obras de arte do mundo antigo e fundavam uma estesia nova, erguida sobre uma arqueografia poética, que atualizava o passado.

No século XVIII, a sociedade de Antiquários, em ação desde o primeiro decênio, começa a publicar a sua revista com o título de Arqueologia. É nessa tradição renascentista que a civilização greco-romana é conhecida e reconhecida. A arte começa a contar com a sua própria história recortada de todas as outras e que contaminará toda a prática da arqueologia, pois alimentará o colecionismo - fome insaciável de peças belas e raras. É a essa tradição que se filia à Arqueologia Clássica.

A Arqueologia, a que é pré-histórica, e que interessa aqui, filia-se a outra tradição dominante do pensamento ocidental. Só no século XIX a História Natural começa a se desdobrar em Ciências Naturais. Foi com Charles Lyell e os seus princípios de geologia, com o reconhecimento das três idades sucessivas (pedra, bronze e ferro) com Thomsen, e a sua popularização através dos museus, com os postulados evolucionistas de Spencer que afirmava que "o progresso não é um 
acidente e sim uma necessidade", com a teoria da evolução de Charles Darwin, que as Ciências Naturais vão se desdobrar.

O surgimento das sociedades científicas, das universidades, dos museus, as revistas especializadas e o empenho dos naturalistas viajantes associado com a realização de grandes expedições de exploração compõem o ambiente intelectual inquieto que marca, de maneira profunda, o século XIX. Como decorrência, ampliam-se a Geologia, a Botânica, a Zoologia, assim como a Anatomia Humana desdobra-se em estudo comparado das raças e evolução do homem. É nessa outra grande tradição do pensamento ocidental que se insinua a pré-história e que, muito posteriormente, se desdobra em Arqueologia Histórica.

A definição de Arqueologia Histórica Brasileira é o campo de saber que pretende dar conta da introdução e do desenvolvimento no território que se transformou na nação brasileira de novas práticas políticas, sociais e econômicas que caracterizavam países europeus em seu processo de expansão territorial e ocupação das terras indígenas na América do Sul.

A estruturação da Arqueologia Histórica, em diferentes países, é recente. Na Inglaterra, a prática da Arqueologia em contexto medieval está presente desde 1840, mas é só em 1957 que surge a Society for Medieval Archaeology. Nos Estados Unidos, cresceu lentamente até a década de 1960, quando se deu a criação, em 1967, da Sociedade de Arqueologia Histórica. No mesmo ano foi criada a Sociedade de Arqueologia Pós-Medieval, na Inglaterra. A Austrália, três anos antes, já havia formado sua sociedade de Arqueologia Histórica. Atualmente, em diferentes países da América Latina e no Canadá, há uma multiplicação de centros de pesquisas, sociedades científicas, cursos de pósgraduação voltados para o estudo dos processos relacionados com o estabelecimento dos europeus. (Meneses1983a; Orser 1996).

AArqueologia Histórica é assim considerada uma disciplina recente no contexto cientifico. No Brasil, embora desde a década de 1930 algumas intervenções tenham sido realizadas em sítios históricos na região Sul, foi apenas a partir da década de 1960 que a Arqueologia, como um todo, e a Arqueologia Histórica, em particular, adquiriram características científicas mais sistemáticas.

Segundo Andrade Lima (1993), já no final da década de 1930, Herman Kruse empenhou-se na localização de "casas fortes", que foram construídas no século XVI, por Gabriel Soares de Souza em suas penetrações no sertão baiano. Nessa mesma época, Loureiro Fernandes desenvolveu um trabalho pioneiro na Serra Negra, no Paraná, quando investigou ossadas humanas e vestígios de argila destinados a lacrar as aberturas na rocha que foram utilizadas para sepultar corpos. Esses túmulos foram identificados como pertencentes a negros quilombolas, mas não foram feitos estudos mais detalhados. Na década de 1940, Virgínia Watson estudou a Ciudad Real do Guaira, antiga vila espanhola quinhentista no Paraná, analisou as cerâmicas e abriu caminho para futuros trabalhos nesse povoado.

Já na década de 1950, ocorrem vários estudos: Padre Luiz Gonzaga Jaeger fez intervenções assistemáticas nas missões jesuíticas de São Nicolau, São Luiz Gonzaga e São Borja. Foram feitas escavações na capela do antigo Colégio dos Jesuítas, em Paranaguá, por Loureiro Fernandes, tendo como objetivo auxiliar os trabalhos de restauração do prédio. Inaugura-se um aspecto que vai marcar a trajetória da Arqueologia Histórica - o desenvolvimento de estudos associados aos trabalhos de restauração.

Continuando com Andrade Lima (1993), durante um longo período, a Arqueologia Histórica brasileira dedica-se ao estudo de prédios coloniais, investiga igrejas, missões, conventos, fortificação e solares etc.. É fortemente impregnada pela ideologia então vigente nas esferas patrimoniais, cuja concepção elitista e arquitetônica de bem cultural privilegia os monumentos de pedra e cal. Dessa forma, a Arqueologia teve, como seu principal interesse, o estudo dos segmentos dominantes da sociedade brasileira. Foi reduzida, na maioria dos casos, a uma técnica a serviço de outras áreas de conhecimento, como a História e a Arquitetura. Operou em um nível meramente arqueográfico, sem explorar o seu potencial interpretativo, ficando em um plano de relativa marginalidade frente à História, à Arquitetura e à própria Arqueologia Pré-histórica.

Analiso, agora, algumas características da pesquisa arqueológica no Brasil, no momento em que surge um maior interesse em relação aos sítios históricos. Na década de 1950, a Arqueologia brasileira passa por um momento bastante importante no que se refere a sua estruturação em termos científicos. São contribuições importantes a Missão Francesa e a influência de pesquisadores america- 
nos. Os arqueólogos franceses, seguindo o modelo adotado pelas várias missões francesas na América do Sul, dedicaram-se aos estudos de sítios de caçadores e dos grafismos rupestres e os pesquisadores americanos voltaram as suas atenções especialmente para os sítios cerâmicos e para os sambaquis (Barreto 1999).

É de particular interesse, a contribuição de Betty Meggers e Clifford Evans, especialmente as pesquisas desenvolvidas no bojo do Programa Nacional de Pesquisa Arqueológica (PRONAPA), ativo no período compreendido entre 1965/70 e que construiu o primeiro panorama da pré-história brasileira. Vou deter-me na contribuição do casal Evans, pois materiais históricos foram recuperados, analisados e interpretados segundo a perspectiva abraçada por eles. Perspectiva esta que se difundiu amplamente no Brasil e, até os dias de hoje, é uma referência. Em um determinado período, especialmente a década de 1970 e até mesmo 1980, as estratégias de campo e de análise adotadas pelo PRONAPA foram recorrentes na arqueologia brasileira. Pode-se dizer que era a maneira preponderante de se fazer pesquisa, muito embora louváveis exceções sempre tivessem se destacado.

Trata-se de uma linha de pesquisa fortemente influenciada pela Ecologia Cultural americana, de Julian Steward, e especialmente pela visão de Betty Meggers que prioriza os fenômenos naturais ao construir interpretações sobre mudança social. No PRONAPA, o casal Evans adotou como estratégia de ataque dos sítios arqueológicos a realização de coletas de superfície e de pequenas sondagens feitas a partir de níveis artificiais. Os materiais foram ordenados segundo a seriação Ford, procedimento que organiza os vestígios a partir de tipologias concebidas para detectar mudanças através do tempo e do espaço. Segundo esta linha de pesquisa, os materiais são classificados segundo as categorias de fase e tradição inspirados em Willey \& Phillips (1955).

Para Meggers \& Evans (1985), fase e tradição mantêm a mesma relação que gênero biológico possui com a espécie, sendo que a tradição persiste por mais tempo e ocupa áreas mais extensas do que a fase. A fase por sua vez é definida segundo uma seqüência seriada e representa a expressão arqueológica de uma comunidade etnográfica.

No que se refere aos sítios cerâmicos, as pesquisas realizadas no âmbito do PRONAPA forneceram um panorama espaço-temporal das tradições arqueológicas encontradas no Brasil que ainda hoje é uma referência importante para a préhistória. No que se refere à análise de outros tipos de sítios, a fragilidade teórico-metodológica dessa linha de pesquisa fica extremamente evidente e este é o caso específico da abordagem de sítios históricos.

É na década de 1960 que surgem os primeiros trabalhos de Arqueologia Histórica efetivamente sistemáticos, tanto no sul como no nordeste do país. No Rio Grande do Sul, seguindo a orientação do PRONAPA, são investigadas as missões jesuíticas e é criada a primeira fase cultural referente ao período histórico, a fase Missões. São os trabalhos de localização de povoados cobertos pela vegetação, análise de materiais provenientes de coletas de superfície e sondagens e identificação de técnicas introduzidas pelos europeus. No nordeste, à mesma época, surgiram pesquisas em fortificações e igrejas de Pernambuco. No decorrer dos anos 1970, os estudos relacionados com as Missões foram enfatizados tanto no sul como no nordeste do Brasil. Os estudos realizados nas Missões Jesuíticas-guarani apontaram para um tema de pesquisa que iria receber atenção significativa dos arqueólogos. São as investigações sobre contatos interétnicos e os fenômenos de aculturação, que seriam aprofundados na década de 80 (Andrade Lima 1993).

No Rio de Janeiro, Ondemar Dias identifica uma cerâmica que denomina de "cabocla" resultado do contato entre índios e europeus, material que passou a integrar a tradição Neobrasiliera e que se refere ao período colonial. Segundo definição apresentada em Chmyz (1976:145), a tradição cultural Neobrasiliera é "....caracterizada pela cerâmica confeccionada por grupos familiares, neobrasileiros ou caboclos, para uso doméstico, com técnicas indígenas e de outras procedências, onde são diagnosticadas as decorações: corrugada, escovada, incisa, aplicada, digitada, roletada, bem como asas, alças, bases planas em pedestal, cachimbos angulares, discos perfurados de cerâmica e pederneira"

A tradição Neobrasileira é um instrumento de análise que pretende dar conta do processo desencadeado com a chegada dos europeus ao que viria ser a nação brasileira. Porém, na maioria dos trabalhos onde se observa o uso do termo, ele está voltado quase exclusivamente para a descrição de cacos cerâmicos e a caracterização das técnicas de 
confecção. Investe-se, especialmente, no estudo da cerâmica colonial, outros materiais eventualmente presentes nos sítios raramente são mencionados.

A visão reducionista desse esquema, fortemente marcado pelo determinismo ambiental, pouco se adequa à interpretação de fenômenos pós-contato com europeu. A riqueza documental sobre este período - quer seja relato de cronistas, de religiosos ou toda a produção sobre o Brasil Colônia, Império e República - mostra a complexidade dos fatos sociais. Evidencia a inadequação dos instrumentos de análise, amplamente utilizados pela Arqueologia brasileira, para dar conta do período histórico. A tradição Neobrasileira, um dos produtos do PRONAPA, teve vida curta.

A restrição de seu uso é um indicador de que rapidamente a comunidade de pesquisadores percebeu que as premissas abraçadas pelo PRONAPA não poderiam dar conta de uma realidade que envolvia os reinos de Portugal, Inglaterra, França e Holanda, diferentes povos indígenas e nações africanas. As nações européias e suas colônias, em pleno mercantilismo e com sofisticado controle de exploração do ambiente, dificilmente poderiam ser estudadas à luz da versão da Ecologia Cultural introduzida no Brasil por Betty Meggers e Clifford Evans.

É nesse contexto científico que surge um dos desdobramentos da Arqueologia, a Arqueologia Histórica. Para avaliar o seu desenvolvimento, e especialmente as relações com a Arqueologia Préhistórica, analisarei as publicações relevantes que divulgam os resultados de pesquisa no Brasil. Optei por fazer um balanço apoiando-me nos anais do III Seminário Goiano, realizado em 1980, e, sempre que possível, nos cadernos de resumos divulgados pela Sociedade de Arqueologia Brasileira (SAB). Informo que não tive acesso nem ao caderno de resumos nem aos anais da reunião da $\mathrm{SAB}$ que ocorreu em 1985.

O III Seminário Goiano foi um momento importante na história da disciplina, pois a comunidade de pesquisadores se reuniu para elaborar uma síntese da ocupação pré-histórica do território nacional. Neste encontro, também, foi amadurecida a idéia de formar uma sociedade de arqueologia.

A escolha em analisar os volumes das reuniões científicas da SAB para acompanhar a constituição da Arqueologia Histórica recai nos seguintes fatos: a associação congrega número significativo de profissionais, a apresentação e publicação de idéias está vinculada apenas à filiação que se dá mediante exigências mínimas e à periodicidade das reuniões. Destaco, ainda, que a SAB é resultado do processo de amadurecimento da disciplina e que para seus congressos são eleitos temas considerados como pertinentes e significativos pela comunidade científica.

Escolhi analisar os cadernos de resumos dos encontros da $\mathrm{SAB}$ pois, diferentes dos anais das reuniões, eles melhor expressam os interesses enfocados em cada reunião. Corroborou minha opção o fato de os anais, muitas vezes, terem sido divulgados de maneira tão tardia que, praticamente, coincidem com a reunião seguinte (este foi o caso da X SAB, em 1999). Além do mais, por diferentes motivos, nem todas as comunicações apresentadas nos encontros resultam em contribuições para os anais dos congressos. Alguns autores preferem divulgar em outros meios e certos trabalhos não têm fôlego para se transformarem em artigo. Dessa forma, considero que os livros de resumos melhor expressam os interesses da comunidade no momento de realização de cada congresso. Infelizmente, não encontrei o programa da III reunião da SAB que ocorreu em Goiânia, em 1985.

Para proceder à análise das contribuições estabeleci 10 categorias: caçadores, pescadores/ coletores, horticultores/ceramistas, nativos, grafismos, antropologia física, teoria e método, abordagens regionais, patrimônio cultural, estudos de região, arqueologia histórica, arqueologia clássica e notícias. A categoria "caçadores" inclui as contribuições que versam sobre o início da ocupação do território brasileiro, as reflexões sobre as tradições Umbu, Humaitá e Itaparica, bem como os estudos de indústrias líticas. "Pescadores/ coletores" refere-se aos grupos sociais que ocuparam o litoral brasileiro, às tradições ou fases denominadas de Macaé e Itaipu, aos estudos sobre sambaquis sujos ou limpos e às adaptações litorâneas. "Horticultores/ceramistas" é a categoria que agrupa os estudos relacionados com as tradições ceramistas e grupos horticultores, já a categoria "nativos" reúne reflexões sobre grupos indígenas quer seja da perspectiva da etnoarqueologia ou da etnohistória.

"Grafismo" aglutina as contribuições sobre pintura e gravura rupestre. "Antropologia Física" reúne os trabalhos que tratam de análise dos esqueletos humanos, já "teoria e método", conforme o próprio título informa, incorpora reflexões 
sobre o tema. Neste caso, é preciso ressaltar que a grande maioria das contribuições trata preferencialmente de métodos e que são raras as reflexões teóricas. O item "patrimônio cultural" trata dos inventários de sítios, das avaliações e dos debates sobre política de preservação. Os "estudos de região" incorporam todos os levantamentos de área e a arqueologia da paisagem. Já a categoria denominada "Arqueologia Histórica" agrupa as reflexões voltadas para o modo de vida que se estabeleceu após a colonização européia. "Arqueologia clássica" agrupa as contribuições sobre Egito, Mediterrâneo e outros. A categoria "notícias" reúne os debates sobre os diferentes meios e os diferentes fins de divulgação (educação, museus, Internet, ...). É, também, o espaço destinado para a divulgação de resultados relacionados com novas técnicas de análise. (Tabela 1 e Gráfico 1).

Quero ressaltar os limites desta classificação que visa exclusivamente delinear a incorporação da temática da Arqueologia Histórica no seio da principal reunião científica de arqueólogos brasileiros. As primeiras reuniões caracterizam-se por tratar e ordenar os temas de maneira bastante empírica e de forma estanque. Com o desenvolvimento da disciplina, eles vão se imbricando, desdobrando-se e tornando-se mais complexos. Um bom exemplo é o grafismo, no início era tratado de maneira isolada, praticamente restrito à descrição de desenhos nas rochas e sua distribuição espacial. Atualmente, há todo um investimento em associá-lo com os vestígios de solo e investigar as regras sociais que orquestraram a sua execução. Com o passar dos anos e com o acúmulo de conhecimento, a ordenação dos temas passou a ser menos empiricista e torna-se uma árdua tarefa enquadrá-los no modelo que regia os primeiros encontros da Sociedade de Arqueologia. Porém, como a Arqueologia Histórica inaugura a sua participação na VI SAB, em 1987, e já se passaram mais sete encontros, optei por ater-me à ordenação temática das primeiras reuniões.

No que se refere especificamente à Arqueologia Histórica e, também, a partir da leitura dos resumos, estabeleci seis categorias: arqueologia de restauração, estudos de caso, estudos de materiais e técnicas de análise, estudos de práticas cotidianas e mentalidades, reflexões sobre teoria e metodologia e notícias. "Arqueologia de restauração" refere-se às pesquisas que estão diretamente relacionadas com os trabalhos de recuperação do patrimônio arquitetônico. Os "estudos de caso" reúnem os resumos que apresentam apenas os dados básicos em relação a um determinado sítio histórico e até mesmo a um conjunto de sítios sem que seja explicitado nenhum tipo de reflexão sobre hábitos ou costumes. Já a categoria "estudo de materiais e técnicas de análise", como deixa claro a denominação escolhida, agrupa comunicações que versam sobre materiais típicos de sítios históricos, tal como a faiança, e técnicas de análise, quer seja de materiais ou do próprio sítio.

A categoria "estudos de práticas cotidianas e mentalidades" reúne os trabalhos que enfocam aspectos da vida cotidiana relacionado com o sítio em estudo (práticas de higiene, poder, espaço, memória), já as "reflexões sobre teoria e metodologia" agrupam os estudos que se caracterizam pela reflexão teórica. "Notícias" é uma categoria bastante heterogênea e reúne apresentações de projetos, notas de intenção de estudo, notícias de sítios e outros.

Bem sei que muitas contribuições poderiam se encaixar em duas ou três categorias estabelecidas mas cada uma delas integra uma única. Muito embora as sessões (sejam simpósios, grupos de trabalho ou mesa redonda) tenham sido preparadas para aprofundar temas específicos e que, portanto, todas as contribuições poderiam ser encaixadas, em bloco, em uma mesma categoria, decidi reordená-las segundo os temas estabelecidos. Procedi desta maneira por considerar que o resumo expressa de maneira mais significativa a questão focal da pesquisa e considerei, também, que, muitas vezes, questões de ordem política também interferem na composição dos membros das sessões. A Tabela 2 enfoca as contribuições de Arqueologia Histórica apresentadas nas reuniões da SAB e a sua respectiva classificação temática. O Gráfico 2, elaborado com os mesmos dados, permite uma melhor visualização da evolução desse campo de saber e, em anexo, estão listados todos os trabalhos que foram analisados.

Na publicação que resultou do seminário de Goiás ficou bem claro quais os temas que os arqueólogos queriam priorizar: paleo-índio, arcaico do litoral e do interior, cultivadores do planalto e do litoral e arte rupestre. Não foi feita qualquer referência sobre Arqueologia Histórica, muito embora alguns pesquisadores já tivessem voltadas suas atenções para o período colonial. Como já mencionei, Virginia Watson já havia realizado 
trabalho com enfoque de Arqueologia Histórica na cidade Real do Guaira, Chmyz $(1963 ; 1964)$ deu continuidade às suas pesquisas. Blasis, em 1961, já havia publicado trabalho considerado pioneiro na Missão Jesuítica de Santo Inácio Mini. Na realidade, desde a década de 60 , ocorreram várias abordagens de sítios históricos.

Logo após o III Seminário Goiano, em 1981, ocorre a I reunião científica da SAB. O livro de resumos conta com 39 contribuições agrupadas em grandes temas: caçadores e coletores, início da agricultura e horticultores, modelos etnográficos para a arqueologia, arte rupestre, temas variados. Nenhuma sessão intitulada arqueologia histórica e nenhuma linha sobre material histórico. Significativamente, apesar de já existir um certo acúmulo de informações, não ocorre nenhuma referência a qualquer tipo de questão relacionada ao período pós-contato com os europeus. Isso indica que, até então, os arqueólogos definiam o seu perfil como estudiosos do período antes do contato com o europeu. Só na reunião de 1987 é que temas como sítios do século XIX, trabalhos sobre restauração, guerras, entre outros, são tratados no âmbito das reuniões da SAB. A Arqueologia Histórica surge na IV reunião da SAB, em 1987, com peso e forte determinação de marcar presença, entre todas as categorias é a que apresenta maior número de contribuições. A partir desse momento, com alguma oscilação, só vai crescer e se desdobrar (ver Tabela 1, Gráfico 1).

É na esfera pública que lida com a preservação do patrimônio histórico cultural da nação que a pesquisa em Arqueologia Histórica ganha evidência. Algumas prefeituras reconhecem a importância do trabalho de arqueólogos. Em São Paulo é celebrado um convênio entre a prefeitura e a Universidade de São Paulo e Margarida Andreatta coordena uma série de estudos. As informações obtidas, apesar de certas dificuldades que marcam o desenvolvimento da pesquisa, começam a influenciar os trabalhos de restauração. Lá também, ocorre o I Seminário do Patrimônio Histórico da Cidade de São Paulo. É um grupo restrito que se reúne e fica claro o confronto entre arqueólogos e arquitetos, os primeiros sendo vistos claramente como empecilho para o cronograma de obras. Ulpiano Bezerra de Meneses explicita que uma nova ordem precisa ser imposta - os trabalhos de arqueologia devem preceder as intervenções arquitetônicas e de restauração.
Logo após, em outubro de 1985, a Secretaria do Patrimônio Histórico Artístico Nacional, atual Instituto do Patrimônio Histórico e Artístico Nacional, órgão responsável pela preservação do patrimônio cultural brasileiro, e a Fundação PróMemória, organizaram o Seminário de Arqueologia Histórica, no Paço Imperial, no Rio de Janeiro. O encontro reuniu um grande número de participantes, cerca de 340 pessoas. Segundo Andrade Lima (1993), nesse momento, a disciplina foi parcialmente resgatada da inferioridade em relação ao campo da pré-história, iniciando uma nova etapa. Foi, de fato, uma surpresa a quantidade e a qualidade de trabalhos apresentados.

Nesses dois seminários, o de São Paulo e o do Rio de Janeiro, fica bem clara uma das características que marcam o início da arqueologia histórica. Surge atrelada ao processo de recuperação da memória nacional que investe de maneira significativa na restauração de prédios e monumentos. Processo que é levado adiante, principalmente por arquitetos e historiadores, e é com os primeiros que se dão os maiores conflitos. Como numa batalha, pois é assim que, segundo Bourdieu (1983), se pode pensar as relações entre as disciplinas - os arqueólogos disputam verba, tempo, espaço e interpretação com os arquitetos, já que são estes profissionais que tocam as obras e, em certas circunstâncias, convocam arqueólogos. Essa situação marcou os trabalhos apresentados nos seminários. Muitos projetos foram concebidos sem a participação de arqueólogos e as equipes tiveram uma série de dificuldades em impor o seu ritmo de trabalho e posições .

A disputa da Arqueologia Histórica é com arquitetos, pois nesse momento a Arqueologia Histórica ainda não produz conhecimento que pudesse contrariar interpretações já existentes. Disputa espaço para realizar trabalhos de campo, em seu próprio ritmo de pesquisa, e não pressionada por cronograma de obra. Significativamente, o embate, nesse momento, não se dá com a História, pois esta disciplina recebe, com certa simpatia, as contribuições de arqueólogos. Para alguns domínios da história, a incorporação de informações obtidas a partir da análise da cultura material é mesmo uma tradição, sendo recorrente nos estudos de Egito e Grécia.

Por outro lado, a própria História começa rever criticamente o potencial informativo do documento escrito, especialmente no que se refere 
ao fato de o documento escrito ser essencialmente representação (Meneses 1983b). Nesse mesmo movimento, começa a valorizar outras evidências da cultura material que, por sua vez, passam a ser consideradas também como documentos.

Os arqueólogos historiadores são implacáveis nos seus argumentos, Arno Kern, Pedro Paulo Funari e Carlos Guimarães, separadamente e em diferentes situações, ressaltam a importância do tipo de informação que pode ser obtida através do estudo da cultura material. Na visão desses autores, a cultura material permite lançar "um novo olhar" sobre determinadas realidades sociais. Entre as várias peculiaridades que a caracterizam, está a possibilidade de dar voz aos segmentos menos privilegiados que não tiveram a oportunidade de registrar, por escrito, a sua experiência social.

Nesse sentido, a cultura material permite desvendar informações que nunca foram mencionadas nos relatos das elites dominantes (religiosa, política ou econômica) por desconhecimento, por não considerar relevante ou simplesmente pelo puro desejo de omitir. Permite estudar, em detalhe, por exemplo a organização nos Quilombos, o seu cotidiano, estratégias de sobrevivência e proteção. Destruir certas pré-noções amplamente divulgadas pela história, quer seja que os Quilombos mantinham-se praticamente isolados ou que todas as Missões eram iguais em decorrência do traçado urbanístico imposto pelas ordens religiosas, etc .... (Funari 2000; Kern 1994)

A pesquisa de Arno Kern: $(1994,1998)$ mostra, de um lado, a complexidade das relações entre jesuítas e Guarani; de outro, as relações do Povo das Missões com outros grupos indígenas, com a coroa espanhola e com a portuguesa sempre à procura de mão de obra já "civilizada". Apresenta, em detalhes, o processo que denomina de "transculturação", a manutenção de uma série de costumes indígenas, a mistura de determinados hábitos em certos domínios (o traçado urbanístico europeu e a permanência de grandes casas para famílias extensas), e a imposição de certos hábitos pelos jesuítas, como o uso do arado por homens.

Arno Kern, historiador de formação e treinado em arqueologia no Rio Grande do Sul, estado que cedo desenvolveu uma sólida tradição de pesquisa em Missões, é um dos primeiros a estabelecer um debate acirrado com a História. Em diversas situações, critica a maioria dos trabalhos de história que se limita a uma análise interna estrutural da comunidade missioneira sem relacioná-la com uma realidade mais ampla na qual está inserida. Pedro Paulo Funari, por sua vez, um dos mais combativos, inúmeras vezes ressalta a especificidade da Arqueologia Histórica (Funari 1991,1996).

Já na SAB, em 1987, a Arqueologia Histórica marca sua presença com 14 comunicações sob a coordenação de Arno Kern. Vários arqueólogos, até então voltados exclusivamente para a préhistória, passam também a divulgar os resultados de estudos de materiais provenientes do período de contato com os europeus. O próprio Arno abandona os estudos em sambaqui e volta-se para o estudo das Missões Jesuíticas, Gabriela Martin apresenta os estudos em Missão Vila Flor, Margarida Andreatta e Dorath Uchôa analisam uma caieira que fabricava a cal proveniente de um sambaqui e Tânia Andrade Lima estuda os sítios históricos do Rio de Janeiro. A partir de 1993 são mais recorrentes os trabalhos no campo da Arqueologia Histórica. É destaque o grupo de trabalho intitulado Arqueologia Africana no Brasil, coordenado por Pedro Paulo Funari e o curso denominado Arqueologia Histórica no Brasil, coordenado por Arno Kern com a participação de Paulo Tadeu de Albuquerque e Tania Andrade Lima.

A maioria dos trabalhos é descritiva, outros são apenas informes de intenções. Alguns são decorrentes de obras de restauração e se limitam a contribuir para o processo de recuperação de prédios e monumentos. O seu número indica o grande peso que essa linha de atuação tem na Arqueologia brasileira. Porém, destacam-se alguns que já apresentam questões mais elaboradas como o estudo do processo de implantação de ordem burguesa na cidade do Rio de Janeiro. Tania Andrade Lima, em 1987, apresenta "a tralha doméstica" recuperada em sítios históricos do Rio de Janeiro. O criativo título de seu trabalho permite vislumbrar a leitura inovadora do modo de vida que se instalou no Brasil com a chegada da corte portuguesa e que teve desdobramentos com "Chá e simpatia", em 1999, título também sugestivo, no qual é investigada como a cerimônia se estruturou na Inglaterra e as feições que tomou no Brasil patriarcal.

Se existia restrição, por parte dos préhistoriadores, em relação àqueles que se voltam para os temas históricos, tal conduta já não se sustenta. Vários profissionais que integram a SAB, 
considerada até então como domínio dos estudiosos do período pré-colonial, passam a dedicar-se ao tema. Em todos os encontros há trabalhos de Arqueologia Histórica e cada vez é maior o número de intervenções (grupos de trabalho, mesas redondas, vídeos, cursos, painéis) (ver Tabela 1 e Gráfico 1).

Por volta de meados da década de 1990, os pesquisadores que se dedicam ao estudo do período colonial consideraram que tinham questões e problemas específicos e iniciaram um movimento para criar uma associação, seguindo, assim, o modelo de outros países. Cabe perguntar, por que, diferente do que ocorreu na Austrália, Inglaterra e Estados Unidos, o projeto não se concretizou. Não creio que a iniciativa de criar uma associação específica não tenha se efetivado em decorrência do pequeno número de profissionais engajado no projeto, já que um grupo restrito de pesquisadores teve fôlego para criar o Fórum de Arqueologia, quando discordaram dos caminhos adotados pela SAB. Até hoje o projeto não se concretizou e parece não ser mais necessário. Pesquisadores que se dedicam ao estudo da Arqueologia Histórica foram presidentes da SAB - Gabriela Martin, eleita em 1991; Arno Kern, em 1993; Paulo Tadeu de Albuquerque, em 1995 e Tania Andrade Lima, em 1999 - e o espaço está aberto para tratamento de temas relacionados com o período após o contato com os europeus.

Fica claro que a arqueologia no Brasil ampliou significativamente o seu campo de estudo, o período pós-contato com europeus passou a ser, também, foco de interesse de muitos estudiosos, especialmente após 1999 quando ocorre uma espécie de boom da Arqueologia Histórica. Considero que o abandono do projeto de criação de uma sociedade voltada para o estudo do período histórico está relacionado com a mudança que ocorreu na própria definição da Arqueologia em países que influenciam a disciplina no Brasil.

Na década de 1960, ocorreu um importante movimento nos Estados Unidos e Inglaterra. Ulpiano Bezerra de Meneses (mimeo) fornece um balanço das contribuições que resumo a seguir. Trata-se de uma reação ao Histórico Culturalismo, approach de pesquisa difundido por Franz Boas e que dominava as pesquisas arqueológicas desde $\mathrm{o}$ início do século passado. Foi um movimento capitaneado por Lewis Binford e que teve como preocupação central tornar a Arqueologia uma disciplina científica. Muitos consideraram que a solução para este problema era incorporar os métodos e fundamentos das ciências experimentais, mas predominou uma perspectiva assumida por David Clarke que tratou de transformar a Arqueologia em ciência, atribuindo-lhe um campo específico, com objetivo e método próprios. Para tornar a Arqueologia uma ciência capaz de explicar diferenças e similitudes culturais inspiraram-se em três linhas de pesquisa. 1) no Evolucionismo Americano, de Leslie White, que procurou estabelecer relações comensuráveis entre energia tecnológica e o desenvolvimento das civilizações; 2) na Ecologia Cultural, de J. Steward, com o seu evolucionismo multilinear - entendido no âmbito das articulações da cultura e meio-mabiente.; 3) No Funcionalismo da antropologia britânica (de Radcliff Brown e Malinoswski) principalmente no conceito de adaptação, que termina por tornar a cultura equivalente a um sistema adaptativo.

Foi um movimento efervescente com significativa produção, novas abordagens e com repercussão importante na própria definição da Arqueologia. Segundo essa corrente teórica, o objeto de estudo é o sistema cultural, quer seja no passado longínquo dos primeiros caçadores quer seja na atualidade. Fica para trás o recorte temporal que desde o início da Arqueologia delimitou esse campo de saber. A disciplina deixa de se restringir a um determinado período (o pré-histórico), etapa na qual não se conta com documentos escritos.

Caracteriza a Nova Arqueologia uma preocupação sistemática em estabelecer analogias com grupos atuais e, portanto, uma valorização dos estudos de etnoarqueologia. São inúmeras as pesquisas com sociedades vivas.

Apesar das fortes críticas que recebeu, algumas bem merecidas, a Nova Arqueologia foi um dos movimentos mais criativos da Arqueologia. Uma verdadeira tempestade de idéias. Convém lembrar que as influências da Nova Arqueologia só chegaram ao Brasil por volta da década de 1980. Segundo Andrade Lima (2000) enquanto nos países de língua inglesa condenavam-se as tipologias, as construções cronológicas, as infindáveis descrições com fim em si mesmas e o método indutivo, no Brasil ocorria um movimento oposto. Florescia uma ecologia cultural bastante equivocada. As exceções são pesquisas de etnoarqueologia, padrões de assentamento abordando caçadores, sambaquieiros e horticultores e, na Arqueologia Histórica, os 
estudos voltados para entender fenômenos de aculturação e a instalação do modo de vida burguês no Brasil colônia e república (Barreto 2000).

Uma avaliação das premissas teórico-metodológicas difundidas pela Arqueologia Processual deixa claro que elas não são adequadas para dar conta de processos de interação e conflito cultural que marcaram o período histórico no Brasil. Refiro-me a toda diversidade de grupos indígenas, os diferentes contingentes europeus (portugueses, franceses, holandeses) com interesses distintos e contraditórios, que abrangem uma enorme gama de motivações que vão desde aspirações religiosas até a mais pura exploração comercial. Completa, ainda, o panora$\mathrm{ma}$ a forte presença de diferentes etnias africanas. Toda esta complexidade, dificilmente, poderia ser aprofundada a partir de uma visão normativa de cultura difundida pela Nova Arqueologia.

É no que se pode chamar de "segunda revolução da Arqueologia", movimento denominado de Arqueologia Pós-processual que a Arqueologia Histórica brasileira, já com o seu lugar assegurado na comunidade acadêmica, vai florescer.

A crítica mais agressiva à Arqueologia Processual veio de Cambridge e começou minando o positivismo da Nova Arqueologia. Critica-se o approach sistêmico, a influência da Ecologia Cultural e dos esquemas evolucionários que dominaram os estudos das sociedades. Ian Hodder, um dos destaques desse movimento, mostrando a influência da Escola de Frankfurt, resiste a toda tentativa de transformar a Arqueologia em uma Ciência Natural. Volta as suas atenções para o artefato enquanto símbolo. Propõe que símbolos materiais refletem e simultaneamente criam a lógica interna que guia as ações práticas para todos os membros da comunidade. Comportamento é negociação entre indivíduos e entre diferentes subgrupos (classes, gêneros e minorias) onde esses símbolos circulam (McIntosh 1996). Em suas interpretações, os processualistas recuperam a abordagem de Leroi-Gourhan, especialmente sua idéia de cadeia de atividades, e apoiam-se no estruturalismo, não na corrente de Lévi-Strauss com sua perspectiva mais transcultural, mas sim no particularismo de Clifford Geertz.

Ian Hodder (1992) proclama que a Arqueologia é o estudo da cultura material, em qualquer tempo e lugar. Desta maneira, fornece total legitimidade aos estudos históricos e aos contemporâneos. Até o lixo, recém-descartado, é estuda- do. Este é o tema de pesquisa, inúmeras vezes mencionado, do projeto coordenado por William Rathje (1996). Trabalho que é utilizado como um exemplo do potencial informativo da cultura material e mostra que geralmente "o que a pessoa diz" é muito diferente "do que a pessoa faz" Rathje e seus colegas coletaram lixo doméstico na cidade de Tucson, Arizona, e estudaram seu conteúdo. $\mathrm{Na}$ análise, ficou claro que as estimativas dos habitantes desta cidade, sobre o total de lixo que eles produzem, é totalmente incorreta. É especialmente equivocada em relação ao descarte de latas de cerveja, sendo esta conduta uma estratégia para camuflar o alto consumo de álcool.

É também uma especificidade do Pósprocessualismo encorajar vozes alternativas na Arqueologia. Ocorre, lentamente, um crescimento do pluralismo interpretativo e a interação de múltiplos pontos de vista para construir conhecimento. Assim, nas últimas duas décadas, a Arqueologia Ocidental passou por processo bastante decisivo de debates, críticas e revisões de linhas teóricas dominantes, desembocando em pluralismo teórico, temático e metodológico jamais visto na história da Arqueologia. Este movimento foi desencadeado pelas críticas de Cambridge à Arqueologia Processual e depois continuou com o aparecimento de um novo leque de perspectivas teóricas. Deste conturbado período surge uma Arqueologia mais reflexiva quanto a sua natureza

Trata-se de um quadro muito mais favorável para o desenvolvimento da Arqueologia Histórica. Não se questiona mais se estudar o período histórico é Arqueologia ou não. Valoriza-se, na análise, o uso de múltiplas fontes - cultura material, documento escrito e discurso - cada uma com suas especificidades para construir interpretações. Enfoca-se o conflito entre segmentos sociais que compartilham e fazem leitura divergente de uma mesma prática social. Entram em foco a Arqueologia de gênero, de classes de idade, classes sociais, diferentes etnias e credos religiosos.

Apoiada na reflexão de Barreto (2000), é pertinente avaliar a repercussão na Arqueologia Brasileira das mudanças ocorridas nos Estados Unidos e Europa. Como já ressaltei, a partir da década de 80 chegam ao país os reflexos da Nova Arqueologia. Velhos temas são tratados sob novas perspectivas. A antigüidade da ocupação do território brasileiro, que vem sendo estudada desde os primórdios da Arqueologia, passa a ser analisa- 
da à luz de teorias sobre a entrada do homem na América. Os sambaquis, outro tema mais que centenário, recebe novo tratamento. Investiga-se a organização social e padrões de assentamento.

Novos temas são incorporados. Processo de mudança, sedentarização, transição para a agricultura e complexificação social. São abandonadas as estáticas categorias de pré-cerâmico, cerâmico ou histórico. Surgem novas abordagens como as pesquisas de etnoarqueologia e ocorre a integração de novas fontes de informação, arqueólogos passam a lidar com dados históricos, lingüísticos e biológicos. AArqueologia Histórica se fortalece.

AArqueologia brasileira, seguindo uma tendência ocidental, é mais auto-reflexiva sobre a própria produção. São significativos os esforços de síntese e as avaliações históricas sobre os rumos da disciplina ou de temas específicos. São destaques as contribuições de Prous (1991), Mendonça de Souza (1991), Funari (1989), Barreto (1999; 2000), Robrahn-González (2000).

Arqueólogos brasileiros fazem enorme esforço para sair do isolamento que aprisiona a disciplina. A série de seminários organizados por Edna Morley, do Instituto do Patrimônio Histórico Artístico Nacional, traz ao Brasil vários profissionais americanos, entre eles Michael Schiffer, J. Parson, Norman Yoffe, Suzanne e Paul Fish. Estas visitas científicas culminam com o que já é considerado um marco do atual período - o Congresso sobre Teoria e Método realizado na Universidade de São Paulo, em 1995. Nele, arqueólogos brasileiros, americanos e franceses sentam, lado a lado, em um profícuo intercâmbio científico. A troca de informação científica substituiu o tradicional treinamento em técnicas especializadas que durante muito tempo caracterizou a contribuição de arqueólogos estrangeiros (Castro Faria 1989).

Com a globalização, a difusão de informações através de meios eletrônicos e a popularização das viagens de avião, os pesquisadores brasileiros passam a freqüentar, com regularidade, os centros mais avançados de Arqueologia.

No primeiro simpósio brasileiro apresentado na Society for American Archaeology, em 1996, denominado "A Panorama of Brazilian Archaeology", coordenado por Maria Dulce Gaspar, Paulo De Blasis e Edna Morley, uma das importantes contribuições é um trabalho de Arqueologia Histórica. Paulo Zanettini apresentou as práticas de guerra adotadas em Canudos, na
Bahia. No esforço para sair do isolamento em que se colocou em decorrência de uma série de opções criticáveis, as Arqueologias (a pré e a histórica) saem juntas para correrem atrás do tempo perdido. Mas significativas, ainda, para a Arqueologia Histórica, são as reuniões de Teoria Arqueológica na América do Sul, iniciadas em 1998. Trata-se de um alinhamento com os colegas da América do Sul com os quais é possível compartilhar as especificidades do fazer Arqueologia nos trópicos. AArqueologia Histórica se faz presente através de um dos organizadores do evento, Pedro Paulo Funari.

Porém, há ainda um longo caminho a percorrer. Segundo a avaliação de Tânia Andrade Lima (2000), são poucos, muito poucos, os que incorporam os preceitos da Nova Arqueologia e muito menos os que acompanham as críticas feitas pelos arqueólogos de Cambridge. Mais raras ainda são as pesquisas que direcionam suas investigações para o estudo de relações de poder e dominação, para aspectos cognitivos e simbólicos, identificando o indivíduo como negociador ativo das regras sociais e admitindo suas escolhas como ideologicamente determinadas, valorizando a estrutura mental, os sistemas de crenças e ideologia e considerando conflito e contradição cultural. O pluralismo interpretativo ainda vai demandar muito tempo para se instalar no país, muito embora, já tenha imprimido algumas de suas marcas na Arqueologia Histórica que mais facilmente incorpora as inovações teóricas.

Apesar de muitos trabalhos ainda serem eminentemente descritivos e outros tantos atrelados ao que se denomina "Arqueologia da Restauração". esse campo da Arqueologia apresenta particularidades interessantes que permitem um desenvolvimento rápido da disciplina que a partir de 1980 se impôs enquanto campo de saber e abriu espaço junto aos arquitetos, historiadores e pré-historiadores. Construiu interpretações inovadoras sobre hábitos, costumes e mentalidades do Brasil colônia e república. Temas nunca imaginados, são explorados. Fala-se de práticas obsessivas em relação à excreção de humores como forma de comportamento disciplinar da sociedade carioca do século XIX, estuda-se globalização (Andrade Lima 1996, 2002).

Cabe pensar o que este domínio da Arqueologia tem de particular. $O$ aspecto ímpar da Arqueologia Histórica é a sua capacidade de dispor simultaneamente do registro documental e do 
registro arqueológico, ou seja, daquilo que foi escrito e o que realmente foi feito. E, da confrontação dos dois, construir interpretações que evidenciem novas leituras da realidade que se propõe a investigar.

Além disso, como sugere Andrade Lima (1993), é preciso destacar o forte apelo emocional das pesquisas realizadas em sítios históricos junto à sociedade, que se identifica profundamente com os materiais europeus e africanos recuperados nas escavações. Brasileiros sentem que ali, de fato, estão os seus antepassados e a sua memória. É uma situação completamente diferente da enfrentada pelos pesquisadores que estudam o modo de vida dos caçadores, sambaquieiros ou horticultores. Há um distanciamento emocional em relação à ancestralidade indígena que a Arqueologia PréHistórica traz à tona.

Um outro aspecto precisa ser considerado. Os pesquisadores que dispõem de documentos escritos sobre os temas de estudo podem rapidamente contar com informações fundamentais para proceder suas análises, como por exemplo, delinear o objeto de pesquisa em seu contexto espaço-temporal. Esta simples tarefa, para os estudiosos do Brasil pré-colonial, implica uma série de procedimentos custosos no que se refere a tempo e investimento financeiro na pesquisa de campo.

Menciono um exemplo brasileiro, para dar uma dimensão local ao problema. A Arqueologia brasileira, desde os seus primórdios, tem se voltado para os estudos de sambaqui. São mais de mil títulos já publicados, centenas de datações radiocarbônicas. É possível imaginar que a abordagem de um problema específico, relacionado com a sociedade sambaquieira, poderia ser facilmente equacionada. Mas esta não é a realidade de pesquisa quando o objeto de estudo é o Brasil antes do contato com os europeus (Barbosa \& Gaspar 1998; Gaspar 1996).

Apenas para realizar uma análise estrutural da cadeia de atividades que resultou no processo de incremento do sambaqui de Jabuticabeira II, Santa Catarina, foram 40 dias de campo de uma equipe composta por 15 profissionais treinados. A equipe estudou 130 metros de perfis, previamente expostos em decorrência da exploração de conchas para o fabrico da cal. Isto quer dizer que não houve escavação, apenas preparação e registro das informações contidas nos perfis. Em uma segunda etapa, com a mesma duração que a anterior e desenvolvida por cinco arqueólogos, teve como objetivo a verificação das informações obtidas através do ataque vertical e melhor entender o programa mortuário; foi feita a decapagem de uma pequena área funerária de $25,5 \mathrm{~m}^{2}$, sendo que a profundidade máxima alcançada foi de $50 \mathrm{~cm}$ nos locais onde havia covas e buracos de estacas. Isto fornece uma dimensão do ritmo diferenciado de produção de dados básicos entre a Arqueologia que conta com documentos escritos e a que se restringe à análise da cultura material (Fish et al. 2000; Gaspar et al. 2002).

Assim, considerando a disposição de toda a comunidade de arqueólogos em sair do isolamento científico que manteve e ainda mantém a disciplina isolada em relação às outras ciências sociais, as facilidades de comunicação decorrentes da globalização, o forte apego afetivo da sociedade brasileira em relação aos materiais provenientes do período histórico e a relativa rapidez com que é possível obter certos dados básicos para sustentar reflexões sobre o período colonial, é possível esperar um forte e rápido desenvolvimento da Arqueologia Histórica. A quantidade de trabalhos apresentada na reunião da SAB, de 2001, ultrapassa meia centena e mostra o vigor desse campo de estudo. Esta previsão não se apóia apenas em números, mas também na criatividade dos estudos. Jardins são tratados como artefatos, investigam-se hábitos da higiene bucal, as redes de serviço de água e esgoto, sistemas de defesa, ataque e comunicação entre fortes. Desvenda-se todo um cotidiano fascinante.

\section{Agradecimentos}

Agradeço a Márcia Barbosa e a Elisa Dalcin Pinheiro por terem auxiliado no levantamento realizado nos livros de resumos da SAB, ao Paulo Zanettini por ter disponibilizado texto inédito e a Angela Buarque pela leitura cuidadosa do original. 


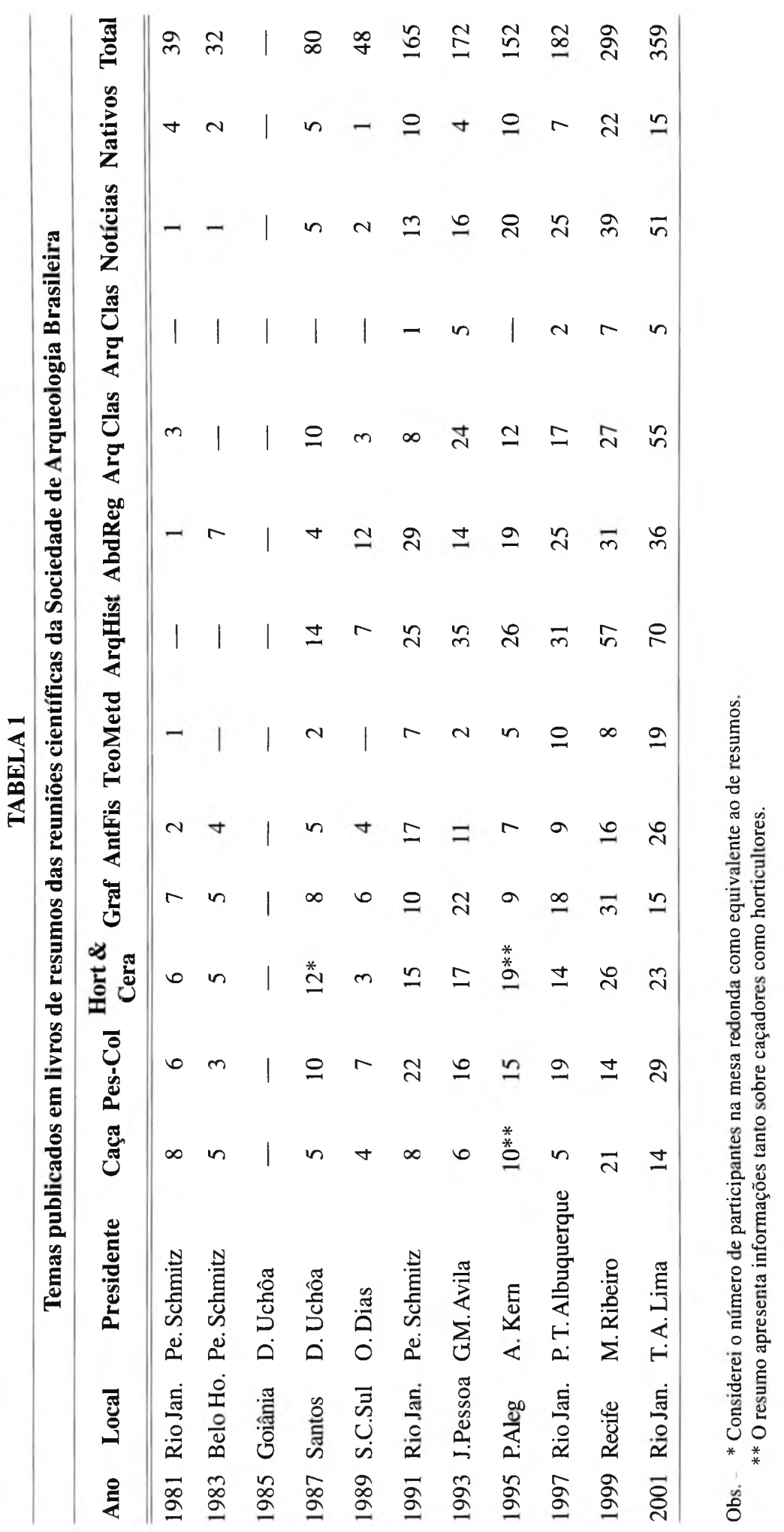




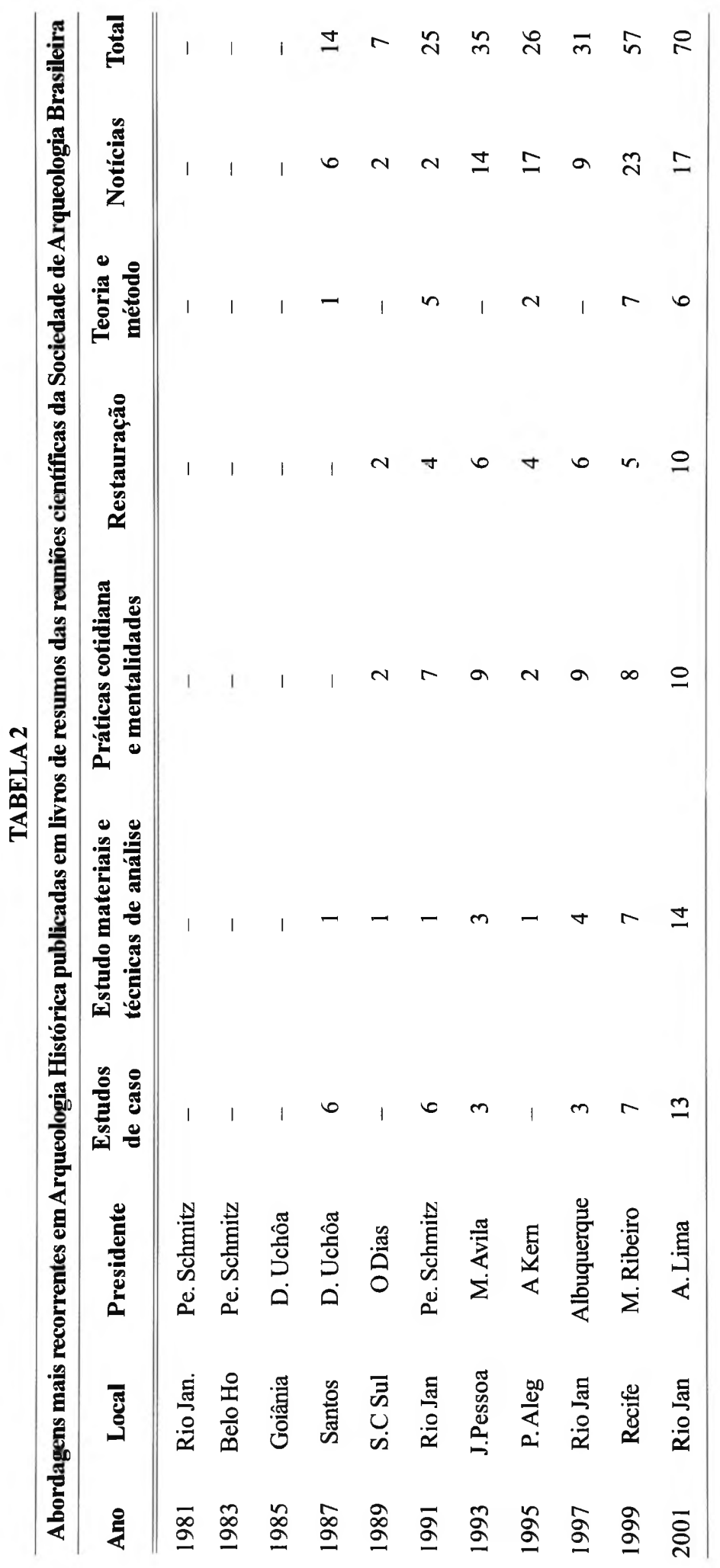




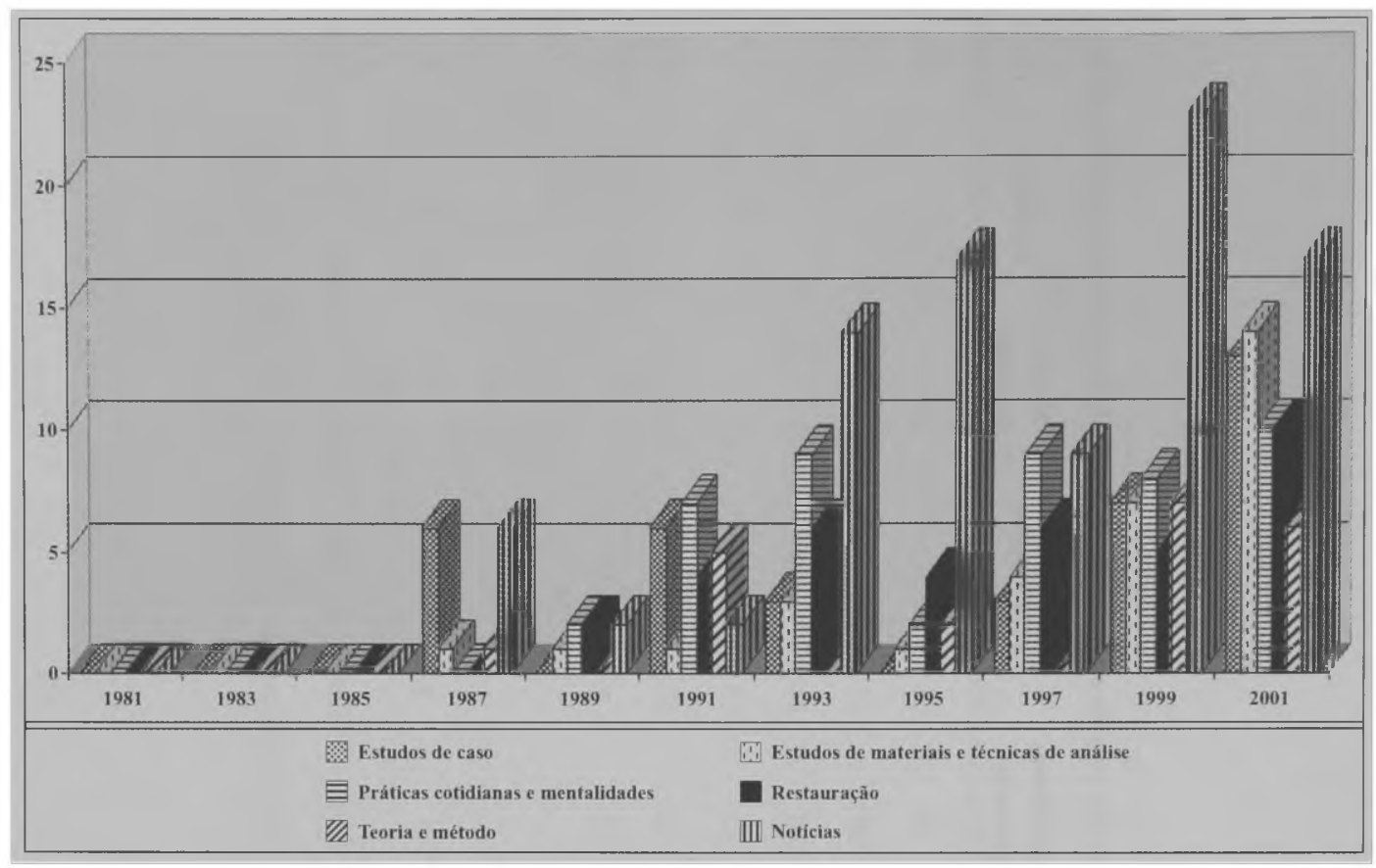

Gráfico 2 - Abordagens mais recorrentes em Arqueologia Histórica publicadas em livros de resumos das reuniões científicas da Sociedade de Arqueologia Brasileira. 


\section{ANEXO}

\begin{tabular}{|c|c|c|c|}
\hline \multicolumn{4}{|c|}{$\begin{array}{c}\text { Classificação dos resumos de Arqueologia Histórica publicados em livros de resumos } \\
\text { das reuniões científicas da Sociedade de Arqueologia Brasileira }\end{array}$} \\
\hline Ano & Abordagens & $\begin{array}{c}\text { Título } \\
\end{array}$ & Autores \\
\hline \multirow[t]{6}{*}{1987} & Estudos de caso & $\begin{array}{l}\text { Intervenções arqueológicas nas missões } \\
\text { jesuíticas do Rio Grande do Sul }\end{array}$ & Kern, A.A. \\
\hline & & $\begin{array}{l}\text { Caieira do Brasil colônia: remanescentes na } \\
\text { "Ilha do Casqueirinho" }\end{array}$ & Andreatta, M.D. \\
\hline & & $\begin{array}{l}\text { Pesquisas arqueológicas na missão Carmelita } \\
\text { da Vila Flor (RN) }\end{array}$ & Martin, G. \& Farraz, S. \\
\hline & & $\begin{array}{l}\text { Escavações arqueológicas na aldeia de São } \\
\text { Nicolau do Rio Pardo, RS, Brasil }\end{array}$ & $\begin{array}{l}\text { Ribeiro, P.A.M.; Ribeiro, C.T. } \\
\text { \& da Silveira, I. }\end{array}$ \\
\hline & & Arqueologia histórica da guerra de Canudos & Zanettini, P.E. \\
\hline & & A mão de obra indígena no Rio de Janeiro & Dias Jr., O. \\
\hline 1987 & $\begin{array}{l}\text { Estudos de } \\
\text { materiais e } \\
\text { técnicas de } \\
\text { análise }\end{array}$ & $\begin{array}{l}\text { A tralha doméstica em meados do século XIX: } \\
\text { um estudo comparado de utensílios cotidianos } \\
\text { em sítios históricos do Rio de Janeiro }\end{array}$ & $\begin{array}{l}\text { Lima, T.A.; da Fonseca, } \\
\text { M.P.R; Sampaio, A.C.O.; } \\
\text { Nepomuceno, A.F-. \& } \\
\text { Martins, A.H.D. }\end{array}$ \\
\hline 1987 & $\begin{array}{l}\text { Teoria e } \\
\text { metodologia }\end{array}$ & Arqueologia e história & Magalhães, M.P. \\
\hline \multirow[t]{6}{*}{1987} & Notícias & $\begin{array}{l}\text { Análise dos vestígios arqueológicos de São } \\
\text { Lourenço em laboratório }\end{array}$ & $\begin{array}{l}\text { Kern, A.A.; Cunha, J.; } \\
\text { Cazetta, M.; Nobre, E.; } \\
\text { Santos, R. \& Ribeiro, C. }\end{array}$ \\
\hline & & $\begin{array}{l}\text { Intervenção arqueológica na missão de São } \\
\text { Lourenço: análise espacial e trabalhos de } \\
\text { campo }\end{array}$ & $\begin{array}{l}\text { Kern, A.A.; Souza, J.O.; } \\
\text { Santos, M.C.; Tochetto, } \\
\text { F.B.; Thadeu, V.T.; Vietta, } \\
\text { K.; Cunha, J.; Santos, R.; } \\
\text { Escosteguy, F. \& Ribeiro, C. }\end{array}$ \\
\hline & & $\begin{array}{l}\text { A pesquisa arqueológica na casa da fundição } \\
\text { do ouro de Goiás: primeiros resultados }\end{array}$ & $\begin{array}{l}\text { da Silva, C.E.F. \& Pardi, } \\
\text { M.L.F. }\end{array}$ \\
\hline & & $\begin{array}{l}\text { O projeto arqueológico e histórico de São } \\
\text { Lourenço }\end{array}$ & Kern, A.A. \& Ribeiro, P.M. \\
\hline & & $\begin{array}{l}\text { A arqueologia histórica no contexto do projeto } \\
\text { de desenvolvimento integral da área do sertão } \\
\text { de Canudos }\end{array}$ & de Ataíde, Y.D.B. \\
\hline & & $\begin{array}{l}\text { Ruínas do Abarabebê e seu entorno: projeto } \\
\text { de preservação }\end{array}$ & Uchôa, D.P. \\
\hline 1989 & $\begin{array}{l}\text { Estudos de } \\
\text { materiais e } \\
\text { técnicas de } \\
\text { análise }\end{array}$ & $\begin{array}{l}\text { Categorias cerâmicas do sítio arqueológico } \\
\text { histórico Casa da Marquesa de Santos }\end{array}$ & Arakaki, F.R. \\
\hline
\end{tabular}


ANEXO (cont.)

\begin{tabular}{|c|c|c|c|}
\hline \multicolumn{4}{|c|}{$\begin{array}{l}\text { Classificação dos resumos de Arqueologia Histórica publicados em livros de resumos } \\
\text { das reuniões científicas da Sociedade de Arqueologia Brasileira }\end{array}$} \\
\hline Ano & Abordagens & $\begin{array}{c}\text { Título } \\
\end{array}$ & Autores \\
\hline \multirow[t]{2}{*}{1989} & Noticias & $\begin{array}{l}\text { Reconstrução histórica do mosteiro de São } \\
\text { Bento de Santos através dos seus testemunhos } \\
\text { arqueológicos: primeiros levantamentos }\end{array}$ & Maximino, E.P.B. \\
\hline & & $\begin{array}{l}\text { Programa arqueológico, histórico e de } \\
\text { recuperação e manejo ambiental da ilha do } \\
\text { Casqueirinho, Cubatão, São Paulo, Brasil }\end{array}$ & Uchôa, D.P. \& Shimizu, GY. \\
\hline \multirow[t]{2}{*}{1989} & $\begin{array}{l}\text { Práticas } \\
\text { cotidianas e } \\
\text { mentalidades }\end{array}$ & $\begin{array}{l}\text { Arquitetura e arqueologia industrial: } \\
\text { reconhecimento e análise do espaço fabril no } \\
\text { município de São Paulo }\end{array}$ & $\begin{array}{l}\text { Couto, E.T.D. \& Campos, } \\
\text { M.C. }\end{array}$ \\
\hline & & $\begin{array}{l}\text { A siderurgia do século XVI ao XVIII na Vila } \\
\text { de São João do Ipanema. Iperú. São Paulo }\end{array}$ & Andreatta, M.D. \\
\hline \multirow[t]{2}{*}{1989} & $\begin{array}{l}\text { Arqueologia de } \\
\text { Restauração }\end{array}$ & $\begin{array}{l}\text { Vale do Anhangabaú - São Paulo. Uma } \\
\text { experiência em arqueologia urbana }\end{array}$ & Juliani, L.J.C.O. \\
\hline & & Missões religiosas no vale do São Francisco & Martin, G. \\
\hline \multirow[t]{5}{*}{1991} & $\begin{array}{l}\text { Teoria e } \\
\text { metodologia }\end{array}$ & Perspectiva da arqueologia histórica no Brasil & Albuquerque, $\mathrm{M}$. \\
\hline & & $\begin{array}{l}\text { Mapa de valorização arqueológica do sítio } \\
\text { urbano: instrumento preventivo de tutela do } \\
\text { patrimônio arqueológico urbano }\end{array}$ & Cazzetta, M. \\
\hline & & Arqueologia africana no Brasil & Funari, P.P.A. \\
\hline & & Arqueologia histórica: arqueologia ou história? & Pacheco, L.M.S. \\
\hline & & Abordagem geoarqueológica de sítios históricos & Lucena, V. \\
\hline \multirow[t]{6}{*}{1991} & Estudos de caso & $\begin{array}{l}\text { Arqueologia histórica/industrial. Bairro da } \\
\text { fundação - São Caetano do Sul - São Paulo }\end{array}$ & Andreatta, M.D. \\
\hline & & $\begin{array}{l}\text { Missões religiosas do século XVII e XVIII: } \\
\text { subsídio para um programa de arqueologia } \\
\text { urbana no estado do Rio Grande do Norte }\end{array}$ & $\begin{array}{l}\text { Albuquerque, P.T.S.; } \\
\text { Cazzetta, M. }\end{array}$ \\
\hline & & $\begin{array}{l}\text { Projeto de arqueologia da Serra do Itapeti - } \\
\text { Capela de Santo Alberto. Mogi das Cruzes, } \\
\text { São Paulo }\end{array}$ & Andreatta, M.D. \\
\hline & & $\begin{array}{l}\text { Pesquisa arqueológica no Forte São José da } \\
\text { Ponta Grossa. Florianópolis - SC }\end{array}$ & $\begin{array}{l}\text { Correa, A.M.M.C. \& } \\
\text { Montardo, D.L. }\end{array}$ \\
\hline & & $\begin{array}{l}\text { A colonização suíça na ilha de Superagüi a } \\
\text { partir de William Mochaud }\end{array}$ & Giovannetti, S. \\
\hline & & $\begin{array}{l}\text { Vale do Anhangabaú - arqueologia e salvamento } \\
\text { em área urbana }\end{array}$ & $\begin{array}{l}\text { Juliani, L.J.C.O. \& } \\
\text { Campos, M.C. }\end{array}$ \\
\hline
\end{tabular}


ANEXO (cont.)

Classificação dos resumos de Arqueologia Histórica publicados em livros de resumos das reuniões científicas da Sociedade de Arqueologia Brasileira

\begin{tabular}{|c|c|c|c|}
\hline Ano & Abordagens & Título & Autores \\
\hline 1991 & $\begin{array}{l}\text { Estudos de } \\
\text { materiais e } \\
\text { técnicas de } \\
\text { análise }\end{array}$ & $\begin{array}{l}\text { A faiança portuguesa do século XVI a XIX no } \\
\text { sítio Vila Flor - RN }\end{array}$ & Albuquerque, P.T.S. \\
\hline \multirow[t]{2}{*}{1991} & Notícias & $\begin{array}{l}\text { Povoamento luso-açorita de Santo Antônio da } \\
\text { Patrulha (RS): resgate do patrimônio histórico } \\
\text {-arqueológico }\end{array}$ & Jacobus, A.L. \\
\hline & & $\begin{array}{l}\text { A calçada do Lorena: um caso feliz de uso, } \\
\text { preservação e dissemida informação } \\
\text { arqueológica em São Paulo }\end{array}$ & Zanettini. P.E. \\
\hline \multirow[t]{7}{*}{1991} & $\begin{array}{l}\text { Práticas } \\
\text { cotidianas e } \\
\text { mentalidades }\end{array}$ & Projeto Ouro Preto. Locus I: casa da festa. & Junqueira, P.A. \\
\hline & & Escavações arqueológicas nas missões guaranis & Kern, A.A. \\
\hline & & $\begin{array}{l}\text { Trabalhos arqueológicos na redução guarani de } \\
\text { São Lourenço Mártir }\end{array}$ & Kern, A.A. \& Oliveira, L.D. \\
\hline & & $\begin{array}{l}\text { O projeto "Langsdorff de Volta": arqueologia } \\
\text { da fazenda da mandioca. Magé, Rio de } \\
\text { Janeiro }\end{array}$ & $\begin{array}{l}\text { Lima, T.A.; Sousa, A.C.; } \\
\text { Martins, A.H.D. \& Carrilho, } \\
\text { Y.O. }\end{array}$ \\
\hline & & $\begin{array}{l}\text { Arqueologia histórica no vale do Paraíba: a } \\
\text { fazenda São Fernando, Vassouras, RJ }\end{array}$ & $\begin{array}{l}\text { Fonseca, M.P.R. \& Lima, } \\
\text { T.A. }\end{array}$ \\
\hline & & $\begin{array}{l}\text { Villa Rica del Spiritu Santo: ruínas de uma } \\
\text { cidade colonial espanhola no interior do Paraná }\end{array}$ & Parellada, C.I. \\
\hline & & $\begin{array}{l}\text { Defesa, ataque, comunicação: a reprodução } \\
\text { das rotinas de um Forte colonial }\end{array}$ & Vianna, $\mathrm{H}$. \\
\hline \multirow[t]{4}{*}{1991} & $\begin{array}{l}\text { Arqueologia de } \\
\text { Restauração }\end{array}$ & $\begin{array}{l}\text { Arqueologia e história das artes - ciências } \\
\text { auxiliares na restauração de bens móveis e } \\
\text { imóveis }\end{array}$ & Meneses, J.L.M. \\
\hline & & $\begin{array}{l}\text { Arqueologia da Praça da Liberdade: a } \\
\text { recuperação da memória urbana }\end{array}$ & Paula, F.L. \& Baeta, A.M. \\
\hline & & Casas de câmara e de cadeia no Ceará & Veloso, F.A.S. \\
\hline & & $\begin{array}{l}\text { A parte e o todo: estudo dos materiais } \\
\text { encontrados na periferia da fonte-reservatório } \\
\text { do Forte de Santo Antonio de Ratones/SC }\end{array}$ & Vianna, H. \\
\hline 1993 & Estudos de caso & $\begin{array}{l}\text { O Forte de Óbidos, uma unidade de defesa na } \\
\text { conquista do norte do Brasil - um projeto de } \\
\text { pesquisa. (C) }\end{array}$ & Lucena, V. \\
\hline
\end{tabular}


ANEXO (cont.)

Classificação dos resumos de Arqueologia Histórica publicados em livros de resumos das reuniões científicas da Sociedade de Arqueologia Brasileira

\begin{tabular}{|c|c|c|c|}
\hline Ano & Abordagens & Título & Autores \\
\hline & & $\begin{array}{l}\text { A pesquisa arqueológica histórica na usina de } \\
\text { força e luz Santa Cruz de Goiás, Goiás. (C) }\end{array}$ & Souza, M.L.S. \\
\hline & & $\begin{array}{l}\text { Arqueologia histórica - antigas redes dos } \\
\text { serviços de águas e esgotos do Recife: } \\
\text { subsídios para o arqueólogo. (C) }\end{array}$ & Menezes, J.L.M. \\
\hline \multirow[t]{3}{*}{1993} & $\begin{array}{l}\text { Estudos de } \\
\text { materiais e }\end{array}$ & $\begin{array}{l}\text { Preservação de objetos metálicos, resgatados } \\
\text { de sítios arqueológicos históricos. (C) }\end{array}$ & Albuquerque, M. \& Lima, A \\
\hline & & $\begin{array}{l}\text { Objetos feitos em osso e queratina provenientes } \\
\text { de sítios históricos do séc. XIX-RJ. (C) }\end{array}$ & $\begin{array}{l}\text { Sousa, A.C. \& Carrilho, } \\
\text { Y.O. }\end{array}$ \\
\hline & & $\begin{array}{l}\text { Traços diagnósticos em padrõe Willow como } \\
\text { marcadores cronológicos de sítios históricos } \\
\text { do século XIX. (PA) }\end{array}$ & Padilha, C. \\
\hline \multirow[t]{11}{*}{1993} & Notícias & $\begin{array}{l}\text { Subsídios documentais para a pesquisa } \\
\text { arqueológica: as missões religiosas no nordeste } \\
\text { brasileiro. (C) }\end{array}$ & Assis, V.M.A. \\
\hline & & La Colonia del Sacramento & Zambetogliris, N.F. \\
\hline & & $\begin{array}{l}\text { Arqueología histórica en la Bahia de } \\
\text { Maldonado.(C) }\end{array}$ & Curbelo, C. \& Perez, L.C. \\
\hline & & $\begin{array}{l}\text { Chiquitos: estrutura das missões jesuíticas do } \\
\text { oriente boliviano no século XVIII. (C) }\end{array}$ & Lima e Costa, I.F. \\
\hline & & $\begin{array}{l}\text { Current research on missions of Alta California, } \\
\text { EUA. (C) }\end{array}$ & Hoover, R.L. \\
\hline & & Arqueologia histórica nas missões guaranis. (C) & Kern, A.A. \\
\hline & & Lições de catecismo em tupi antigo. (C) & Sena, C.P. \\
\hline & & $\begin{array}{l}\text { A companhia de Jesus e a formação do espaço } \\
\text { urbano de Niterói. (C) }\end{array}$ & Brandão, R.P. \\
\hline & & $\begin{array}{l}\text { Escavações em Igreja jesuítica do séc.XVI: } \\
\text { mostra fotográfica. (PA) }\end{array}$ & Guerra, E. \\
\hline & & $\begin{array}{l}\text { Projeto arqueológico, ecológico, antropológico, } \\
\text { histórico, museológico e turístico do município } \\
\text { de Ubatuba, estado de São Paulo, SP. Sítio } \\
\text { arqueológico do Mar Virado. (PA) }\end{array}$ & Uchôa, D.P. \\
\hline & & $\begin{array}{l}\text { La arqueología urbana en la Colonia del } \\
\text { Sacramento. Uruguay. (PA) }\end{array}$ & Zambetogliris, N.F. \\
\hline
\end{tabular}




\section{ANEXO (cont.)}

\begin{tabular}{|c|c|c|c|}
\hline \multicolumn{4}{|c|}{$\begin{array}{l}\text { Classificação dos resumos de Arqueologia Histórica publicados em livros de resumos } \\
\text { das reuniões científicas da Sociedade de Arqueologia Brasileira }\end{array}$} \\
\hline Ano & Abordagens & $\begin{array}{c}\text { Título } \\
\end{array}$ & Autores \\
\hline & & $\begin{array}{l}\text { Forte de Óbidos - arqueologia de um } \\
\text { monumento.(V) }\end{array}$ & $\begin{array}{l}\text { Albuquerque, M.; Santos, C. } \\
\text { \& Lucena, V. }\end{array}$ \\
\hline & & Projeto Fortaleza dos Reis Magos. (V) & $\begin{array}{l}\text { Fagundes, J.E. \& } \\
\text { Spencer, W.B. }\end{array}$ \\
\hline & & $\begin{array}{l}\text { Fotointerpretación en arqueología histórica. Isla } \\
\text { Gorriti-departamento de Maldonado-Uruguay }\end{array}$ & Cluchy, M.E.F. \\
\hline & & $\begin{array}{l}\text { Projeto arqueológico reserva biológica Atol das } \\
\text { Rocas. }\end{array}$ & $\begin{array}{l}\text { Albuquerque, P.T.S. \& } \\
\text { César, P. }\end{array}$ \\
\hline \multirow[t]{9}{*}{1993} & $\begin{array}{l}\text { Práticas } \\
\text { cotidianas e } \\
\text { mentalidades }\end{array}$ & $\begin{array}{l}\text { Uma unidade religiosa no Brasil Colonial- } \\
\text { estudo arqueológico da Igreja da Graça, } \\
\text { Olinda-PE. (C) }\end{array}$ & Albuquerque, $\mathrm{M}$. \\
\hline & & $\begin{array}{l}\text { Fortaleza dos reis magos: uma fronteira de } \\
\text { contato. (C) }\end{array}$ & $\begin{array}{l}\text { Albuquerque, P.T.S.; } \\
\text { Pacheco, L.S.; Spencer, B. } \\
\text { \& Lago, C. }\end{array}$ \\
\hline & & $\begin{array}{l}\text { Higiene e saúde nos lixos domésticos do Rio } \\
\text { de Janeiro - século XIX. (C) }\end{array}$ & $\begin{array}{l}\text { Lima, T.A.; Sousa, A.C.; } \\
\text { Ferreira, L.F.; Araújo, A. \& } \\
\text { Rangel,A. }\end{array}$ \\
\hline & & $\begin{array}{l}\text { Análise da malha urbana de Villa Rica del } \\
\text { espiritu Santo (1592-1632)/Fênix-PR. (C) }\end{array}$ & Parellada, C.I. \\
\hline & & $\begin{array}{l}\text { De morcegos e caveiras a cruzes e livros: a } \\
\text { representação da morte em cemitérios cariocas } \\
\text { do século XIX (estudo de identidade e } \\
\text { mobilidade sociais). (C) }\end{array}$ & Lima, T.A. \\
\hline & & $\begin{array}{l}\text { Costumes funerários no Brasil: um banco de } \\
\text { dados. (PA) }\end{array}$ & Galvão, V. \\
\hline & & $\begin{array}{l}\text { A pesquisa arqueológica na usina de força e } \\
\text { luz, Santa Cruz de Goiás, Goiás. (PA) }\end{array}$ & Souza, M.L \\
\hline & & $\begin{array}{l}\text { Louça branca e comportamento social no } \\
\text { século XIX. (PA) }\end{array}$ & Symanski, L.C.P. \\
\hline & & $\begin{array}{l}\text { Projeto de arqueologia histórica: "Ruínas do } \\
\text { Abarebebê". (PA) }\end{array}$ & Uchôa, D.P. \& Cazzetta, M. \\
\hline \multirow[t]{3}{*}{1993} & $\begin{array}{l}\text { Arqueologia de } \\
\text { Restauração }\end{array}$ & $\begin{array}{l}\text { Arqueologia histórica-Capela Santo Alberto. } \\
\text { Mogi das Cruzes - São Paulo. (C) }\end{array}$ & Andreatta, M.D. \\
\hline & & $\begin{array}{l}\text { Arqueologia histórica do Solar da Marqueza } \\
\text { de Santos. (C) }\end{array}$ & $\begin{array}{l}\text { Campos, M.C. \& Juliani, } \\
\text { L.J.C.O. }\end{array}$ \\
\hline & & Arquitetura franciscana: uma trajetória. (C) & Mello Neto, U.P. \\
\hline
\end{tabular}


ANEXO (cont.)

Classificação dos resumos de Arqueologia Histórica publicados em livros de resumos das reuniões científicas da Sociedade de Arqueologia Brasileira

\begin{tabular}{|c|c|c|c|}
\hline Ano & Abordagens & Título & Autores \\
\hline & & $\begin{array}{l}\text { Intervenção arqueológica na casa Fernão Dias; } \\
\text { Pedro Leopoldo - Minas Gerais. (C) }\end{array}$ & Paula, F.L.; Veloso, T.G \& col. \\
\hline & & $\begin{array}{l}\text { La arqueologia urbana en la colonia del Sacramento. } \\
\text { Uruguay. (C) }\end{array}$ & Zambetogliris, N.F. \\
\hline & & Projeto Fortaleza dos Reis Magos. (PA) & $\begin{array}{l}\text { Albuquerque, P.T.S.; } \\
\text { Pacheco, L.S.; Spencer, } \\
\text { W.B.; Lago, C.; Barreto, } \\
\text { I.C. \& Moura, S.B. }\end{array}$ \\
\hline \multirow[t]{2}{*}{1995} & $\begin{array}{l}\text { Teoria e } \\
\text { metodologia }\end{array}$ & $\begin{array}{l}\text { Método e teoria no projeto Arqueologia Histórica } \\
\text { Missioneira. (C) }\end{array}$ & Kern, A.A. \\
\hline & & $\begin{array}{l}\text { La concepción simbólica del espacio. Un ejemplo } \\
\text { a partir de la arqueología histórica. (C) }\end{array}$ & Curbelo, C. \\
\hline 1995 & $\begin{array}{l}\text { Estudos de } \\
\text { materiais e } \\
\text { técnicas de } \\
\text { análise }\end{array}$ & $\begin{array}{l}\text { Cultura material européia do sítio arqueológico } \\
\text { histórico RG-23 - Rio Grande, RS - Brasil. (PA) }\end{array}$ & Ognibeni, D. \\
\hline \multirow[t]{10}{*}{1995} & Notícias & $\begin{array}{l}\text { Intervenções arqueológicas em Porto Alegre, RS, } \\
\text { Brasil o exemplo de dois sítios históricos na área } \\
\text { central da cidade. (C) }\end{array}$ & Cappelletti, A. \& Tocchetto, F. \\
\hline & & $\begin{array}{l}\text { Sistematização crono-espacial de unidades } \\
\text { funcionais em Pernambuco: uma abordagem de } \\
\text { pré-escavação. (C) }\end{array}$ & Albuquerque, M. \& Lucena, V. \\
\hline & & $\begin{array}{l}\text { A presença francesa no nordeste do Brasil no } \\
\text { século XVI: uma contribuição da história à } \\
\text { arqueologia. (C) }\end{array}$ & Guerra, M.E. \\
\hline & & $\begin{array}{l}\text { Aproximación al estudio de un modelo de } \\
\text { construcción rural. (C) }\end{array}$ & Caggiano, M.A. \\
\hline & & $\begin{array}{l}\text { O levantamento arqueológico de sítios de engenhos } \\
\text { na parte sul da ilha de Santa Catarina. (C) }\end{array}$ & Silva, O.P. \\
\hline & & A capitania de Itamaracá no século XVI. (C) & Galvão, V. \\
\hline & & La colonia del Sacramento. (C) & Zambetogliris, N.F. \\
\hline & & $\begin{array}{l}\text { Archaeological research at the presidio of Santa } \\
\text { Barbara, California. (C) }\end{array}$ & Hoover, R.L. \\
\hline & & A história da redução de São Joaquim. (PA) & Herberts, A.L. \\
\hline & & Pesquisa arqueológica em Porto Alegre. (PA) & $\begin{array}{l}\text { Cappelletti, A. ; Tocchetto, } \\
\text { F. \& Osório, S. }\end{array}$ \\
\hline
\end{tabular}


ANEXO (cont.)

\begin{tabular}{|c|c|c|c|}
\hline \multicolumn{4}{|c|}{$\begin{array}{l}\text { Classificação dos resumos de Arqueologia Histórica publicados em livros de resumos } \\
\text { das reuniões científicas da Sociedade de Arqueologia Brasileira }\end{array}$} \\
\hline \multirow[t]{7}{*}{ Ano } & Abordagens & Título & Autores \\
\hline & & $\begin{array}{l}\text { A informatização do projeto Arqueologia } \\
\text { Histórica Missioneira. (PA) }\end{array}$ & Krebs, D.T. \\
\hline & & $\begin{array}{l}\text { Arqueologia histórica missioneira: informatização } \\
\text { dos dados cartográficos e topográficos. (PA) }\end{array}$ & Lemos, V.D.C. \\
\hline & & $\begin{array}{l}\text { Programa de arqueologia urbana para } \\
\text { Fortaleza. (PA) }\end{array}$ & Praciano, V. \& Cazzetta, M. \\
\hline & & Arqueologia missioneira: 10 anos de história. (V) & $\begin{array}{l}\text { Severo, F.; Golin, T. \& } \\
\text { Soares, A. }\end{array}$ \\
\hline & & Arqueologia histórica missioneira - ano dez. (E) & Barcellos, A. \\
\hline & & $\begin{array}{l}\text { Reconstituição do povoado missioneiro de São } \\
\text { João Batista. }\end{array}$ & Amoedo, A.P.B. \\
\hline \multirow[t]{2}{*}{1995} & $\begin{array}{l}\text { Práticas } \\
\text { cotidianas e } \\
\text { mentalidades }\end{array}$ & $\begin{array}{l}\text { A cerâmica como fonte documental para a } \\
\text { reconstituição do cotidiano no sítio arqueológico } \\
\text { de São Miguel das missões-RS-Brasil. (C) }\end{array}$ & Uessler, C.O. \\
\hline & & $\begin{array}{l}\text { Refugos domésticos e práticas de despejo no } \\
\text { século XIX: um estudo de caso. (C) }\end{array}$ & $\begin{array}{l}\text { Lima, T.A.: Souza, A.C.; } \\
\text { Symanski, L.C. \& Thomaz, } \\
\text { L.V. }\end{array}$ \\
\hline \multirow[t]{4}{*}{1995} & $\begin{array}{l}\text { Arqueologia de } \\
\text { Restauração }\end{array}$ & $\begin{array}{l}\text { Arqueologia de salvamento: estudo de caso } \\
\text { na charqueada São João. (C) }\end{array}$ & Soares, A.L.R. \\
\hline & & $\begin{array}{l}\text { O solar da Travessa Paraíso: exemplo de } \\
\text { arqueologia histórica no município de Porto } \\
\text { Alegre. (C) }\end{array}$ & Carle, C.B. \& Oliveira,A.T.D. \\
\hline & & $\begin{array}{l}\text { Solar da Marqueza de Santos. Arqueologia } \\
\text { histórica. (C) }\end{array}$ & $\begin{array}{l}\text { Campos, M.C. \& Juliani, } \\
\text { L.J.C.O. }\end{array}$ \\
\hline & & $\begin{array}{l}\text { Pesquisa arqueológica histórica no sub-solo do } \\
\text { Museu Paulista. (C) }\end{array}$ & Andreatta, M.D. \\
\hline \multirow[t]{3}{*}{1997} & Estudos de caso & $\begin{array}{l}\text { Contribuições da arqueologia para a interpretação } \\
\text { do Quilombo dos Palmares. (S) }\end{array}$ & Funari, P.P.A. \\
\hline & & $\begin{array}{l}\text { Assentamentos negros no norte-fluminense - } \\
\text { identificação de localização. (C) }\end{array}$ & $\begin{array}{l}\text { Azevedo Netto, C.X.; } \\
\text { Amantino, M. \& Lotufo, C.A. }\end{array}$ \\
\hline & & $\begin{array}{l}\text { Projeto histórico arqueológico Jardim das } \\
\text { Princesas. (E) }\end{array}$ & \\
\hline 1997 & $\begin{array}{l}\text { Estudos de } \\
\text { materiais e } \\
\text { técnicas de } \\
\text { análise }\end{array}$ & $\begin{array}{l}\text { Etnobotânica dos sítios arqueológicos históricos } \\
\text { em Goiás. (C) }\end{array}$ & $\begin{array}{l}\text { Veloso, T.P.G.; Cardoso, } \\
\text { J.S. \& Guimarães, C.M. }\end{array}$ \\
\hline
\end{tabular}




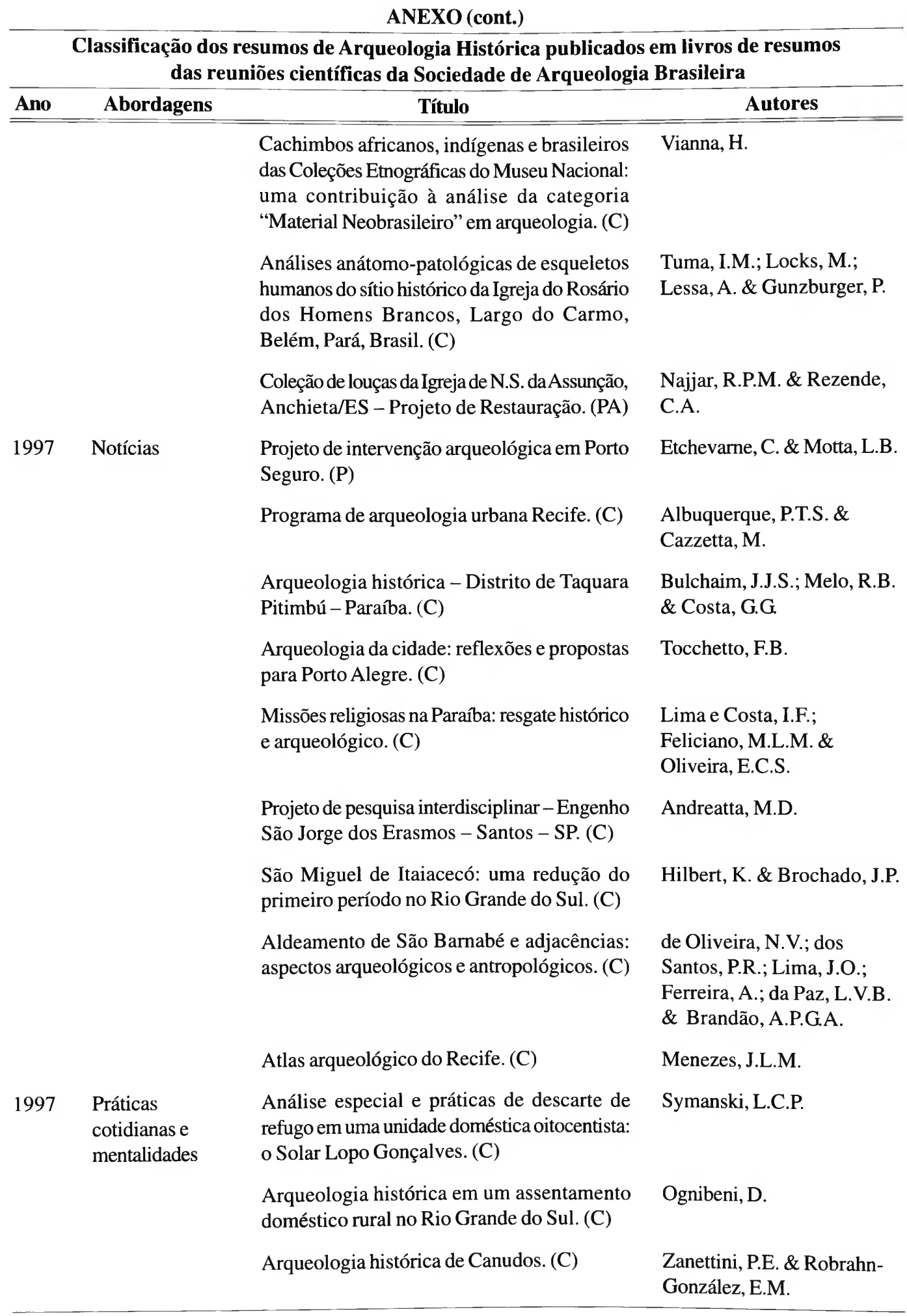


ANEXO (cont.)

\begin{tabular}{|c|c|c|c|}
\hline \multicolumn{4}{|c|}{$\begin{array}{l}\text { Classificação dos resumos de Arqueologia Histórica publicados em livros de resumos } \\
\text { das reuniões científicas da Sociedade de Arqueologia Brasileira }\end{array}$} \\
\hline Ano & Abordagens & Título & Autores \\
\hline & & $\begin{array}{l}\text { Cemitério Santana: a morte entre o moderno e } \\
\text { o tradicional na sociedade goianiense. (C) }\end{array}$ & Carvalho, H.B. \\
\hline & & $\begin{array}{l}\text { Pichações em Belo Horizonte: uma } \\
\text { etnoarqueologia de pinturas rupestres } \\
\text { urbanas. (C) }\end{array}$ & Isnardis, A. \\
\hline & & $\begin{array}{l}\text { Jardins como artefatos: o Passeio Público do } \\
\text { Rio de Janeiro no século XIX. (C) }\end{array}$ & Martins, C.C. \\
\hline & & $\begin{array}{l}\text { Breve estudo sobre estruturas de queima } \\
\text { (fogões, fornalhas e fornos) em sítios do Projeto } \\
\text { de Salvamento Histórico Arqueológico da UHE } \\
\text { Serra da Mesa, GO. (C) }\end{array}$ & $\begin{array}{l}\text { Cardoso, J.S.; Zaroni, L.; } \\
\text { Veloso, T.P.G. \& Guimarães, } \\
\text { C.M. }\end{array}$ \\
\hline & & $\begin{array}{l}\text { Analisando o núcleo urbano do Rio de Janeiro } \\
\text { na mudança de ordens - uma arqueologia da } \\
\text { paisagem. (C) }\end{array}$ & Minetti, A. \\
\hline & & $\begin{array}{l}\text { Hábitos de higiene bucal discutidos a partir dos } \\
\text { vestígios materiais - século XIX. (C) }\end{array}$ & Sant'Ana, V.B. \\
\hline \multirow[t]{6}{*}{1997} & $\begin{array}{l}\text { Arqueologia de } \\
\text { Restauração }\end{array}$ & $\begin{array}{l}\text { Atividades arqueológicas na } 4^{\mathrm{a}} \text { Etapa de } \\
\text { Restauração do Mercado Público Cental de } \\
\text { Porto Alegre. (C) }\end{array}$ & Landa, B.S. \\
\hline & & $\begin{array}{l}\text { Catedral Velha }- \text { Natal/RN: uma experiência } \\
\text { em restauração. (C) }\end{array}$ & $\begin{array}{l}\text { Albuquerque, P.T.S.; Barreto, } \\
\text { I.C.R. \& Moura, S.B. }\end{array}$ \\
\hline & & $\begin{array}{l}\text { As intervenções arqueológicas da campanha } \\
\text { de } 1994 \text { na Igreja do Rosário dos Homens } \\
\text { Brancos (Largo do Carmo, Belém). (C) }\end{array}$ & Kern, A.A. \\
\hline & & Arquitetura franciscana: o Museu de Tudo. (C) & Mello Neto, U.P. \\
\hline & & $\begin{array}{l}\text { Sítio arqueológico histórico Capela Santo Alberto: } \\
\text { escavação, reconstrução e restauro. (PA) }\end{array}$ & Andreatta, M.D. \\
\hline & & $\begin{array}{l}\text { Evidências arqueológicas da Região da Serra } \\
\text { do Itapety - Mogi das Cruzes SP. }\end{array}$ & $\begin{array}{l}\text { Andreatta, M.D. \& } \\
\text { Chermann, D. }\end{array}$ \\
\hline \multirow[t]{3}{*}{1997} & $\begin{array}{l}\text { Teoria e } \\
\text { metodologia }\end{array}$ & $\begin{array}{l}\text { A arqueologia histórica/industrial e o Portinho } \\
\text { da Bertioga. (C) }\end{array}$ & Maximino, E.P.B. \\
\hline & & $\begin{array}{l}\text { Edifícios demolidos do bairro do Recife - área } \\
\text { do Pilar. (C) }\end{array}$ & Menezes, J.L.M. \\
\hline & & $\begin{array}{l}500 \text { Anos de implantação do sistema colonial } \\
\text { português no nordeste do Brasil - a contribuição } \\
\text { da arqueologia histórica. (C) }\end{array}$ & Albuquerque, M. \& Lucena, V. \\
\hline
\end{tabular}


ANEXO (cont.)

\begin{tabular}{|c|c|c|c|}
\hline \multicolumn{4}{|c|}{ ANEXO (cont.) } \\
\hline \multicolumn{4}{|c|}{$\begin{array}{l}\text { Classificação dos resumos de Arqueologia Histórica publicados em livros de resumos } \\
\text { das reuniões científicas da Sociedade de Arqueologia Brasileira }\end{array}$} \\
\hline Ano & Abordagens & Título & Autores \\
\hline & & $\begin{array}{l}\text { Frontera del desierto. Perspectiva transdisciplinaria } \\
\text { de la arqueologia histórica argentina. (C) }\end{array}$ & Austral, A. \& Rocchietti, A.M. \\
\hline & & $\begin{array}{l}\text { La expanción capitalista a tierras antárticas. El } \\
\text { caso de la península Byers, Isla Livingston, } \\
\text { Shetland del Sur. (C) }\end{array}$ & Senatore, M.X. \& Zarankin, A. \\
\hline & & $\begin{array}{l}\text { Entre la historia y la arqueología: problemas } \\
\text { lógicos y nuevas perspectivas. (C) }\end{array}$ & $\begin{array}{l}\text { Cuaranta, P.L. \& Escudero, } \\
\text { C.S. }\end{array}$ \\
\hline & & $\begin{array}{l}\text { Arquitetura como tecnologia do poder no } \\
\text { mundo capitalista. (C) }\end{array}$ & Zarankin, A. \\
\hline \multirow[t]{7}{*}{1999} & Estudos de caso & $\begin{array}{l}\text { Cultura material, descoberta e colonização do } \\
\text { Brasil: uma síntese sócio-cultural ibero-indígena.(C) }\end{array}$ & Kern, A.A. \\
\hline & & $\begin{array}{l}\text { O bairro da Ribeira: sua evolução histórica e } \\
\text { as transformações do seu espaço. (C) }\end{array}$ & $\begin{array}{l}\text { Madeiros, I.H.A. \& } \\
\text { Silva, M.L. }\end{array}$ \\
\hline & & $\begin{array}{l}\text { Arqueologia histórica: Taquara - Distrito de } \\
\text { Pitimbú - PB. (C) }\end{array}$ & $\begin{array}{l}\text { Lima e Costa, I.F. \& } \\
\text { Lucena, M.T. }\end{array}$ \\
\hline & & $\begin{array}{l}\text { A missão religiosa dos padres de Santo } \\
\text { Antônino em Joanes, Ilha de Marajó - um } \\
\text { estudo arqueológico. (C) }\end{array}$ & Lopes, P.R.C. \\
\hline & & $\begin{array}{l}\text { O bairro da Ribeira: sua evolução histórica e } \\
\text { as transformações do seu espaço. (C) }\end{array}$ & $\begin{array}{l}\text { Medeiros, I.H.A. \& Silva, } \\
\text { M.L. }\end{array}$ \\
\hline & & $\begin{array}{l}\text { O sitio arqueológico Serra da Cacaria, Floresta } \\
\text { - PE: um sítio nos brejos de altitude. (C) }\end{array}$ & Silva Jr, L.S. \\
\hline & & $\begin{array}{l}\text { A paisagem da cidade: arqueologia da área } \\
\text { central de Porto Alegre no século XIX. (C) }\end{array}$ & Thiesen, B.V. \\
\hline \multirow[t]{5}{*}{1999} & $\begin{array}{l}\text { Estudos de } \\
\text { materiais e } \\
\text { técnicas de } \\
\text { análise }\end{array}$ & $\begin{array}{l}\text { O estudo da telha na arqueologia histórica, uma } \\
\text { proposta de sistematização: a experiência na } \\
\text { Igreja da Venerável Ordem Terceira de São } \\
\text { Francisco da Penitência, Rio de Janeiro/RJ. (C) }\end{array}$ & $\begin{array}{l}\text { Macedo, J.; Suarez, S.M. \& } \\
\text { Najjar, R. }\end{array}$ \\
\hline & & $\begin{array}{l}\text { Austeridade e limitações do cotidiano: as louças } \\
\text { dos primeiros colonizadores da região da UHE } \\
\text { - Machadinho (RS). (C) }\end{array}$ & Symanski, L.C.P. \\
\hline & & Artefatos de vidro no Forte do Brum. (C) & Guerra, E. \\
\hline & & $\begin{array}{l}\text { A beleza que se põe na mesa - "a faiança } \\
\text { grossa" do Forte do Brum. (PA) }\end{array}$ & Tavares, G. \\
\hline & & $\begin{array}{l}\text { Na paz e na guerra - os cachimbos brancos } \\
\text { do Forte do Brum. (C) }\end{array}$ & Cavalcante, $\mathrm{L}$. \\
\hline
\end{tabular}


ANEXO (cont.)

\begin{tabular}{|c|c|c|c|}
\hline \multicolumn{4}{|c|}{$\begin{array}{l}\text { Classificação dos resumos de Arqueologia Histórica publicados em livros de resumos } \\
\text { das reuniões científicas da Sociedade de Arqueologia Brasileira }\end{array}$} \\
\hline Ano & Abordagens & $\begin{array}{r}\text { Título } \\
\end{array}$ & Autores \\
\hline \multirow{16}{*}{1999} & \multirow{16}{*}{ Notícias } & $\begin{array}{l}\text { Colonia del Sacramento. Loza portuguesa } \\
\text { siglos XVII - XVIII }\end{array}$ & Zambetogliris, N.F. \\
\hline & & $\begin{array}{l}\text { Os cachimbos vermelhos do Forte do Brum - } \\
\text { Recife - PE. (PA) }\end{array}$ & Pereira, A. \\
\hline & & $\begin{array}{l}\text { O sítio histórico arqueológico Santa Clara - } \\
\text { um marco da colonização no vale do rio Mucuri } \\
\text { no século XIX - MG. (C) }\end{array}$ & $\begin{array}{l}\text { Baeta, A.M.; Paula, F.L. \& } \\
\text { Mazzoni Filho, M. }\end{array}$ \\
\hline & & Arqueologia da Sé, Salvador (BA). (C) & $\begin{array}{l}\text { Etchevarne, C.A.; Palermo } \\
\text { Neto, F. \& Souza, A.C. }\end{array}$ \\
\hline & & $\begin{array}{l}\text { Ocupações humanas nos municípios de Porto } \\
\text { Seguro e Santa Cruz Cabrália: primeiras } \\
\text { abordagens. (C) }\end{array}$ & $\begin{array}{l}\text { Etchevarne, C.A.; Cardoso, } \\
\text { T.; Motta, L.B. \& } \\
\text { Nascimento, L.A.V. }\end{array}$ \\
\hline & & $\begin{array}{l}\text { Arqueologia em Praia do Forte e na Casa da } \\
\text { Torre de Garcia D'Ávila. (C) }\end{array}$ & Soares, I.D.C. \& col. \\
\hline & & $\begin{array}{l}\text { Características arquitetônicas das missões } \\
\text { religiosas na Paraíba - Distrito de Taquara - } \\
\text { Pitimbú. (C) }\end{array}$ & $\begin{array}{l}\text { Lima e Costa, I.F. \& } \\
\text { Feliciano, M.L.M. }\end{array}$ \\
\hline & & O traçado do caminho das tropas. (C) & $\begin{array}{l}\text { Oliveira, L.D.; Silva, A.F.; } \\
\text { Bentlin, A. \& Morais, M. }\end{array}$ \\
\hline & & $\begin{array}{l}\text { Escavações no Registro de Santa Vitória - } \\
\text { RS. (C) }\end{array}$ & $\begin{array}{l}\text { Oliveira, L.D.; Silva, A.F.; } \\
\text { Bentlin, A. \& Morais, M. }\end{array}$ \\
\hline & & $\begin{array}{l}\text { Salvamento arqueológico - Sítio Taboatão- } \\
\text { Mogi das Cruzes - SP. (C) }\end{array}$ & $\begin{array}{l}\text { Andreatta, M.D.; Chermann, } \\
\text { C.; Fernandes, V.C. \& } \\
\text { Tomiyama, N.H. }\end{array}$ \\
\hline & & $\begin{array}{l}\text { Estudo de valoração do subsolo arqueológico } \\
\text { urbano do núcleo central de Fortaleza, Ceará. (C) }\end{array}$ & $\begin{array}{l}\text { Mesquita, M.H.; Veras, } \mathrm{O} \text {. } \\
\text { \& Cazzetta, M. }\end{array}$ \\
\hline & & $\begin{array}{l}\text { Sítio histórico São Francisco: contribuição à } \\
\text { arqueologia histórica. (C) }\end{array}$ & Bornal, W.G. \\
\hline & & $\begin{array}{l}\text { Processo de formação e desenvolvimento dos } \\
\text { bairros do Recife. (C) }\end{array}$ & Canto, A.C.L. \& Schneider, \\
\hline & & $\begin{array}{l}\text { Parque "Quinta da Boa Vista", Rio de Janeiro: } \\
\text { aspectos históricos e arqueológicos. (C) }\end{array}$ & $\begin{array}{l}\text { E.R.M. } \\
\text { Niemeyer, H. \& Zaroni, L. }\end{array}$ \\
\hline & & $\begin{array}{l}\text { Missões religiosas na Paraíba: resgate histórico e } \\
\text { arqueológico-municípiode Pitimbu-Taquara.(C) }\end{array}$ & $\begin{array}{l}\text { Lima e Costa, I.F.; Lucena, } \\
\text { M.T. \& Fanco, M.I.M. }\end{array}$ \\
\hline & & $\begin{array}{l}\text { Remanescentes coloniais no nordeste - portos } \\
\text { e barracas do nordeste do Brasil. (C) }\end{array}$ & Milfont, $\mathrm{M}$. \\
\hline
\end{tabular}


ANEXO (cont.)

Classificação dos resumos de Arqueologia Histórica publicados em livros de resumos das reuniões científicas da Sociedade de Arqueologia Brasileira

\begin{tabular}{|c|c|c|c|}
\hline Ano & Abordagens & Título & Autores \\
\hline & & $\begin{array}{l}\text { Projeto a Grande Vila Boa / Subprojeto } \\
\text { Ouro Fino. (C) }\end{array}$ & Souza, M.A.T. \\
\hline & & $\begin{array}{l}\text { Salvamento arqueológico - Sítio Taboão - } \\
\text { Mogi das Cruzes - SP. (PA) }\end{array}$ & Andreatta, M.D. \\
\hline & & Arqueología subacuática en Uruguay. (C) & Lezama, A. \\
\hline & & $\begin{array}{l}\text { Intervenção de resgate em uma unidade de } \\
\text { produção açucareira do século XVI: o engenho } \\
\text { do Taciminim. (C) }\end{array}$ & Nascimento, L.A.V. \\
\hline & & $\begin{array}{l}\text { A iconografia no planejamento da prospecção } \\
\text { arqueológica. (PA) }\end{array}$ & $\begin{array}{l}\text { da Silva, A.S.N.F.; Araújo, } \\
\text { J.C.S.; Rodrigues, W.N. \& } \\
\text { Ferreira, Z.A. }\end{array}$ \\
\hline & & $\begin{array}{l}\text { Projeto arqueológico Tremembé - Ceará - } \\
\text { Brasil. (C) }\end{array}$ & $\begin{array}{l}\text { Nascimento, A.; Gomes, J.V. } \\
\text { \& Luna, S. }\end{array}$ \\
\hline & & $\begin{array}{l}\text { Cidadania e pertencimento: uma experiência de } \\
\text { interação entre arqueologia e educação } \\
\text { patrimonial.(C) }\end{array}$ & $\begin{array}{l}\text { Tocchetto, F.B. \& dos Reis, } \\
\text { J.A. }\end{array}$ \\
\hline & & $\begin{array}{l}\text { Levantamento dos bens arqueológicos } \\
\text { associados às ruínas de Ciudad Real del } \\
\text { Guayrá, com propostas para o } \\
\text { desenvolvimento turístico e gestão } \\
\text { patrimonial.(C) }\end{array}$ & $\begin{array}{l}\text { Chmyz, I.; Chmyz, J.C.G. \& } \\
\text { Brochier, L.L. }\end{array}$ \\
\hline & & Centro histórico de Araruna. (C) & $\begin{array}{l}\text { Costa, I.F.L.; Feliciano, } \\
\text { M.L.M. \& Freire, E.M.C. }\end{array}$ \\
\hline \multirow[t]{6}{*}{1999} & $\begin{array}{l}\text { Práticas } \\
\text { cotidianas e } \\
\text { mentalidades }\end{array}$ & $\begin{array}{l}\text { Arqueologia da paisagem em um contexto } \\
\text { fabril da ordem escravocrata: fábrica de } \\
\text { pólvora-RJ (século XIX). (C) }\end{array}$ & Sousa, A.C. \\
\hline & & $\begin{array}{l}\text { Vestígios domésticos em unidades rurais de } \\
\text { Porto Seguro. (C) }\end{array}$ & Cardoso, $\mathrm{T}$. \\
\hline & & $\begin{array}{l}\text { O ovo da serpente: uma arqueologia do } \\
\text { capitalismo embrionário no Rio de Janeiro, } \\
\text { século XIX. (C) }\end{array}$ & Lima, T.A. \\
\hline & & $\begin{array}{l}\text { Chá e simpatia: uma estratégia de gênero no } \\
\text { Rio de Janeiro oitocentista. (C) }\end{array}$ & Lima, T.A. \\
\hline & & $\begin{array}{l}\text { A religiosidade como fator de preservação de } \\
\text { um monumento. (C) }\end{array}$ & Silva, A.M.C. \& Silva, M.B. \\
\hline & & $\begin{array}{l}\text { Exposição ricos e pobres no século XIX: uma } \\
\text { arqueologia da diferença. (PA) }\end{array}$ & Tocchetto, F.B. \& Costa, F.M. \\
\hline
\end{tabular}


ANEXO (cont.)

\begin{tabular}{|c|c|c|c|}
\hline \multicolumn{4}{|c|}{$\begin{array}{l}\text { Classificação dos resumos de Arqueologia Histórica publicados em livros de resumos } \\
\text { das reuniões científicas da Sociedade de Arqueologia Brasileira }\end{array}$} \\
\hline Ano & Abordagens & Título & Autores \\
\hline & & $\begin{array}{l}\text { Colonia del Sacramento. Casa de los } \\
\text { Gobernadores. (C) }\end{array}$ & Zambetogliris, N.F. \\
\hline & & $\begin{array}{l}\text { Os caminhos da maniçoba na serra da } \\
\text { Capivara, São Raimundo Nonato - Piauí. (PA) }\end{array}$ & Oliveira, A.S.N. \\
\hline \multirow[t]{5}{*}{1999} & $\begin{array}{l}\text { Arqueologia de } \\
\text { Restauração }\end{array}$ & $\begin{array}{l}\text { O Outeiro de Santa Catarina: um resgate de } \\
\text { emergência. (C) }\end{array}$ & Maximino, E.P.B. \\
\hline & & Projeto Casa de Orações dos Jesuítas. (C) & Soares, I.D.C. \& col. \\
\hline & & $\begin{array}{l}\text { Arqueologia histórica e a restauração de } \\
\text { monumentos: a experiência na Igreja de Nossa } \\
\text { Senhora da Assunção, Espírito Santo. (C) }\end{array}$ & Najjar, R. \\
\hline & & $\begin{array}{l}\text { A igreja da Venerável Ordem Terceira de São } \\
\text { Francisco da Penitência: arqueologia num } \\
\text { programa de restauração. (C) }\end{array}$ & $\begin{array}{l}\text { Najjar, R.; Silva, R.C.P.; } \\
\text { Fortuna, C.A.; Plens, C.R. } \\
\text { \& Goulart, M.C. }\end{array}$ \\
\hline & & Restauração do sítio histórico de Acauã. (C) & $\begin{array}{l}\text { Lima e Costa, I.F.; } \\
\text { Feliciano, M.L.M.; Freire, } \\
\text { E.M.C. \& Chianca, M.F.S. }\end{array}$ \\
\hline \multirow[t]{2}{*}{2001} & $\begin{array}{l}\text { Teoria e } \\
\text { metodologia }\end{array}$ & $\begin{array}{l}\text { Lecturas de la sociedad moderna: cultura } \\
\text { material, discursos y practicas cotidianas. (S) }\end{array}$ & Zarankin,A. \& Senatore, M.X. \\
\hline & & $\begin{array}{l}\text { A arqueologia em sítios históricos - tópicos } \\
\text { para uma releitura epistemológica das reflexões } \\
\text { teóricas e práticas arqueológicas recentes. (S) }\end{array}$ & Kern, A.A. \\
\hline \multirow[t]{7}{*}{2001} & Estudos de caso & Arqueologia Histórica do novo milênio. (S) & Funari, P.P.A. \\
\hline & & $\begin{array}{l}\text { O papel da Arqueologia Histórica no mundo } \\
\text { globalizado. (S) }\end{array}$ & Lima, T.A. \\
\hline & & $\begin{array}{l}\text { Estilos de vida: uma forma de ruptura hacia la } \\
\text { cultura material. (GT) }\end{array}$ & Therrien, $\mathrm{M}$. \\
\hline & & $\begin{array}{l}\text { Metodologia e técnicas de levantamento de } \\
\text { unidades arqueológicas em centros urbanos: a } \\
\text { experiência de Porto Alegre. (C) }\end{array}$ & Thiesen, B.V. \\
\hline & & $\begin{array}{l}\text { Inferências sócio-históricas no âmbito do sítio } \\
\text { arqueológico da antiga Sé de Salvador. (C) }\end{array}$ & $\begin{array}{l}\text { Etchevarne, C.; Souza, A.C. } \\
\text { \& Palermo, F. }\end{array}$ \\
\hline & & $\begin{array}{l}\text { Prospecções arqueológicas na área do Colégio } \\
\text { dos Jesuítas - Salvador (BA) }\end{array}$ & $\begin{array}{l}\text { Fernandes, H.L.A. \& Mota, } \\
\text { GB. }\end{array}$ \\
\hline & & $\begin{array}{l}\text { Pesquisa arqueológica dos remanescentes da } \\
\text { Igreja de São Francisco de Assis (séc. XVI) no } \\
\text { sítio Outeiro da Glória-Porto Seguro/BA. (C) }\end{array}$ & Nascimento, L.A.V. \\
\hline
\end{tabular}




\section{ANEXO (cont.)}

\begin{tabular}{|c|c|c|c|}
\hline \multicolumn{4}{|c|}{$\begin{array}{l}\text { Classificação dos resumos de Arqueologia Histórica publicados em livros de resumos } \\
\text { das reuniōes científicas da Sociedade de Arqueologia Brasileira }\end{array}$} \\
\hline Ano & Abordagens & Título & Autores \\
\hline & & $\begin{array}{l}\text { Escavações arqueológicas na catedral de São } \\
\text { Pedro, Rio Grande, RS, Brasil. (C) }\end{array}$ & $\begin{array}{l}\text { Mentz Ribeiro, P.A. \& Penha, } \\
\text { A.P. }\end{array}$ \\
\hline & & $\begin{array}{l}\text { Arqueologia da primeira Sé do Brasil: os } \\
\text { materiais costrutivos. (PA) }\end{array}$ & Costa, C.A.S. \\
\hline & & $\begin{array}{l}\text { RS.JA. } 17 \text { - Casa do Riachuelo - uma visão } \\
\text { histórica através da pesquisa. (PA) }\end{array}$ & Santos, P.A.G. \\
\hline & & $\begin{array}{l}\text { Prospecção arqueológica em residência } \\
\text { oitocentista do conjunto histórico da Praça XV, } \\
\text { município de Florianópolis - SC. (PA) }\end{array}$ & Comerlatto, F. \\
\hline & & $\begin{array}{l}\text { La transformación del aisaje en un sector } \\
\text { pampeano a mediados del siglo XIX. Un } \\
\text { abordaje a la arqueología histórica }\end{array}$ & Caggiano, M.A. \\
\hline & & $\begin{array}{l}\text { Arqueologia histórica em Vila Valqueire, RJ. } \\
\text { O sítio Rochedo }\end{array}$ & $\begin{array}{l}\text { Dias, O.; Carvalho, E. \& } \\
\text { Nascimento, G. }\end{array}$ \\
\hline & & $\begin{array}{l}\text { As lapas do Itacambiraçu: arqueologia de uma } \\
\text { ocupação no século XX }\end{array}$ & $\begin{array}{l}\text { Guimarães, C.M. \& Reis, } \\
\text { F.M.M. }\end{array}$ \\
\hline & & $\begin{array}{l}\text { Abastecimento de água na cidade de São Paulo } \\
\text { no final do século XIX: o Sistema Cantareira - } \\
\text { exemplo de arqueologia industrial }\end{array}$ & Vilar, D.D. \& Fonseca, F.P. \\
\hline & & $\begin{array}{l}\text { Entre senzalas e quilombos: "comunidades do } \\
\text { mato" em Vassouras do oitocentos }\end{array}$ & Agostini, C. \\
\hline & & $\begin{array}{l}\text { Negros ou índios? Prática mutilatória na } \\
\text { primeira catedral do Brasil }\end{array}$ & Líryo, A. \& Carvalho, C. R. \\
\hline \multirow[t]{6}{*}{2001} & $\begin{array}{l}\text { Estudos de } \\
\text { materiais e }\end{array}$ & $\begin{array}{l}\text { Caracterização química de faianças antigas } \\
\text { portuenses. (GT) }\end{array}$ & Castro, F. \\
\hline & & Faiança portuguesa: uma reflexão. (GT) & Fernandes, I.M. \\
\hline & & $\begin{array}{l}\text { Análise da faiança portuguesa: controvérsias e } \\
\text { estratégias. (GT) }\end{array}$ & Albuquerque, $\mathrm{M}$. \\
\hline & & $\begin{array}{l}\text { Lacerâmica portuguesa Colônia Del Sacramento: } \\
\text { Uruguay. (GT) }\end{array}$ & Zambetogliris, N.F. \\
\hline & & Avança Tietê: faiança colonial. (GT) & Zanettini, P.E. \\
\hline & & $\begin{array}{l}\text { A faiança portuguesa-demarcador cronológico } \\
\text { na arqueologia brasileira }\end{array}$ & Albuquerque, P.T. \\
\hline
\end{tabular}


ANEXO (cont.)

\begin{tabular}{|c|c|c|c|}
\hline \multicolumn{4}{|c|}{$\begin{array}{l}\text { Classificação dos resumos de Arqueologia Histórica publicados em livros de resumos } \\
\text { das reuniões científicas da Sociedade de Arqueologia Brasileira }\end{array}$} \\
\hline Ano & Abordagens & $\begin{array}{c}\text { Título } \\
\end{array}$ & Autores \\
\hline & & $\begin{array}{l}\text { Muitas bordas, poucos fundos: reciclagem de } \\
\text { faianças portuguesas dos séculos XVII e } \\
\text { XVIII. (GT) }\end{array}$ & Lima, T.A. \\
\hline & & $\begin{array}{l}\text { Sepultamentos no espaço sagrado; levantamento } \\
\text { de registros de óbitos da primeira catedral do } \\
\text { Brasil (antiga igreja da Sé de Salvador-BA). (C) }\end{array}$ & $\begin{array}{l}\text { Tavares, A.C.P. \& Moraes, } \\
\text { J.M. }\end{array}$ \\
\hline & & $\begin{array}{l}\text { As amostras faunísticas da Igreja de São } \\
\text { Lourenço dos Índios-Niterói/RJ.(C) }\end{array}$ & Almeida, M.B. \\
\hline & & $\begin{array}{l}\text { Caracterização microanalítica de artefatos } \\
\text { metálicos de sítios históricos do Estado do Rio } \\
\text { de Janeiro.(C) }\end{array}$ & $\begin{array}{l}\text { Campos, G.N. \& } \\
\text { Solorzano,G. }\end{array}$ \\
\hline & & $\begin{array}{l}\text { Arqueologia da primeira Sé do Brasil: os } \\
\text { materiais ósseos humanos. (PA) }\end{array}$ & Porto, K.S. \\
\hline & & $\begin{array}{l}\text { Arqueologia da primeira Sé do Brasil: materiais } \\
\text { cerâmicos de uso doméstico. (PA) }\end{array}$ & Barbosa, M.K. \\
\hline & & $\begin{array}{l}\text { Identificação das faianças inglesas azuis e } \\
\text { brancas recuperadas no antigo cais da Praça } \\
\text { XV, Rio de Janeiro. (PA) }\end{array}$ & Pinheiro, E.D. \\
\hline & & $\begin{array}{l}\text { Platos y escudillas portuguesas en la mesa de } \\
\text { Colonia del Sacramento. (PA) }\end{array}$ & $\begin{array}{l}\text { Zambetogliris, N.F. \& } \\
\text { Garibaldi, E.V. }\end{array}$ \\
\hline \multirow[t]{7}{*}{2001} & Notícias & $\begin{array}{l}\text { Casa da Torre de Garcia d'Ávila: Aarqueologia } \\
\text { reescreve a sua história. (C) }\end{array}$ & Soares, I.D.C. \\
\hline & & $\begin{array}{l}\text { Dois grafismos quinhentistas no estado da } \\
\text { Bahia.(C) }\end{array}$ & Almeida, GA. \& Madeira, A. L. \\
\hline & & $\begin{array}{l}\text { Antiga fábrica de vinho de caju Tito Silva \& } \\
\text { Cia.(PB): pesquisas arqueológicas e educação } \\
\text { patrimonial. (C) }\end{array}$ & Canto, A.C.L. \\
\hline & & $\begin{array}{l}\text { Projeto para o resgate histórico e arqueológico } \\
\text { do registro de Santa Vitória: levantamento } \\
\text { histórico como suporte para o salvamento } \\
\text { arqueológico. (C) }\end{array}$ & Silva, A. F. \\
\hline & & $\begin{array}{l}\text { Sitio Lavras de Afonso Sardinha Jaraguá - } \\
\text { SP. (P) }\end{array}$ & Andreata, M \& col. \\
\hline & & $\begin{array}{l}\text { Cultura material e possibilidades de intervenção } \\
\text { no Forte Sant' Ana, Ilha de Santa Catarina. (P) }\end{array}$ & Comerlato, F.; \\
\hline & & $\begin{array}{l}\text { Prevenindo os impactos urbanos em áreas de } \\
\text { potencialidades arqueológicas. (PA) }\end{array}$ & Maximino, E.P. \& Goularti, D \\
\hline
\end{tabular}


ANEXO (cont.)

\begin{tabular}{|c|c|c|c|}
\hline \multicolumn{4}{|c|}{$\begin{array}{c}\text { Classificação dos resumos de Arqueologia Histórica publicados em livros de resumos } \\
\text { das reuniões científicas da Sociedade de Arqueologia Brasileira }\end{array}$} \\
\hline Ano & Abordagens & Título & Autores \\
\hline & & $\begin{array}{l}\text { A Sé antiga: arqueologia urbana e memória } \\
\text { social. (V) }\end{array}$ & $\begin{array}{l}\text { Etchevarne, C.; de Sousa, } \\
\text { A.C. \& Oliveira, J.O. }\end{array}$ \\
\hline & & Arqueologia no Jardim da Luz - São Paulo & Campos, M.C. \\
\hline & & $\begin{array}{l}\text { Expressões do corpo e do espírito:cultura } \\
\text { material escrava em sítios rurais do Mato } \\
\text { Grosso, séculos XVIII e XIX }\end{array}$ & $\begin{array}{l}\text { Souza, M.A.T. \& Symanski, } \\
\text { L.C.P. }\end{array}$ \\
\hline & & $\begin{array}{l}\text { A contribuição da arqueologia para o resgate } \\
\text { da história dos excluídos na Zona da Mata } \\
\text { Mineira }\end{array}$ & $\begin{array}{l}\text { de Oliveira, A.P.P.L. \& } \\
\text { Simões, M.C.S.R. }\end{array}$ \\
\hline & & $\begin{array}{l}\text { Escavando "desaparecidos" em cemitério no } \\
\text { Rio de Janeiro }\end{array}$ & de Oliveira, N.V. \\
\hline & & $\begin{array}{l}\text { Guido Tomás Marlière: texto e contexto de um } \\
\text { genocídio }\end{array}$ & de Sousa, J.L.P. \\
\hline & & $\begin{array}{l}\text { A relevância da literatura de viajantes e } \\
\text { cronistas: possibilidades e limites na arqueologia }\end{array}$ & Paríso, M.H.B. \\
\hline & & $\begin{array}{l}\text { As obras geográficas árabes em Al-Andalus: } \\
\text { contribuição para a arqueologia }\end{array}$ & Teixeira, $\mathrm{S}$. \\
\hline & & $\begin{array}{l}\text { A literatura de viajantes e cronistas: possibilidades } \\
\text { e limites na arqueologia }\end{array}$ & Luft, V.J. \\
\hline & & Arqueologia da paisagem urbana & de Morais, D. \\
\hline \multirow[t]{6}{*}{2001} & $\begin{array}{l}\text { Práticas } \\
\text { cotidianas e } \\
\text { mentalidades }\end{array}$ & $\begin{array}{l}\text { Práticas de descarte de refugo e mudanças de } \\
\text { visão de mundo em um ambiente rural - o sítio } \\
\text { Fazenda Camurugi (BA). (S) }\end{array}$ & Simanky, L.C. \\
\hline & & $\begin{array}{l}\text { Entre práticas e discursos: a construção social } \\
\text { do espaço no contexto de Goiás do século } \\
\text { XVIII. (S) }\end{array}$ & Souza, M.A.T. \\
\hline & & $\begin{array}{l}\text { As representações da Sé: polissemia e } \\
\text { recursividade da cultura material. (C) }\end{array}$ & Souza, A.C. \\
\hline & & $\begin{array}{l}\text { Arqueologia, história e paisagem: o caso da } \\
\text { Juréia. (C) }\end{array}$ & Cali, P. \\
\hline & & $\begin{array}{l}\text { Uma discussão sobre práticas e apropriações } \\
\text { da cultura material em unidades domésticas da } \\
\text { Porto Alegre oitocentista. (C) }\end{array}$ & Tochetto, F.B. \\
\hline & & $\begin{array}{l}\text { Vestígios materiais de uma vila operária: um } \\
\text { estudo das modificações comportamentais no } \\
\text { operariado paulista no século XIX. (C) }\end{array}$ & Plens, C.R. \\
\hline
\end{tabular}




\section{ANEXO (cont.)}

Classificação dos resumos de Arqueologia Histórica publicados em livros de resumos das reuniões científicas da Sociedade de Arqueologia Brasileira

\begin{tabular}{|c|c|c|c|}
\hline Ano & Abordagens & Título & Autores \\
\hline & & $\begin{array}{l}\text { Hierarquia e distribuição de itens de consumo } \\
\text { em sítios rurais do Mato Grosso, séculos XVIII } \\
\text { e XIX. (C) }\end{array}$ & Symanski, L.C.P. \\
\hline & & $\begin{array}{l}\text { Análise espacial das armações catarinenses e } \\
\text { suas estruturas remanescentes: um estudo } \\
\text { através da arqueologia histórica. (C) }\end{array}$ & Comerlato, F; \\
\hline & & $\begin{array}{l}\text { Charqueadas pelotenses no século XIX: } \\
\text { consolidação do poder no espaço ocupado. (C) }\end{array}$ & Ognibeni, D.O. \\
\hline & & $\begin{array}{l}\text { Sítio Fazenda de Baixo: o estudo de caso em } \\
\text { arqueologia da paisagem. (C) }\end{array}$ & Cardoso, J.S. \& Veloso, T.P.G \\
\hline \multirow[t]{10}{*}{2001} & $\begin{array}{l}\text { Arqueologia de } \\
\text { Restauração }\end{array}$ & $\begin{array}{l}\text { Resgates arqueológicos em unidades } \\
\text { religiosas. (GT) }\end{array}$ & Albuquerque, $\mathrm{M}$. \\
\hline & & $\begin{array}{l}\text { Mosteiro de Santa Clara-a-Velha de Coimbra. } \\
\text { A arqueologia num mosteiro suspenso no } \\
\text { tempo. (GT) }\end{array}$ & Santos, P.C.B.A. \\
\hline & & $\begin{array}{l}\text { O arqueólogo de estrutura em projetos de } \\
\text { restauração.(GT) }\end{array}$ & Albuquerque, P.T. \\
\hline & & Arqueologia e restauração arquitetônica. (GT) & Najjar, R. \\
\hline & & $\begin{array}{l}\text { A importância da arqueologia para a } \\
\text { restauração.(GT) }\end{array}$ & Ribeiro, R.T. M. \\
\hline & & $\begin{array}{l}\text { O papel da arqueologia dentro de um projeto } \\
\text { de restauração arquitetônica: o exemplo da } \\
\text { Igreja dos Reis Magos/ES. (C) }\end{array}$ & Najjar, R. \& col. \\
\hline & & $\begin{array}{l}\text { Arqueologia e arquitetura - sítio Capela Santo } \\
\text { Alberto - séc. XVII - reconstruir sem } \\
\text { destruir. (C) }\end{array}$ & Andreatta, M.D. \& col. \\
\hline & & $\begin{array}{l}\text { Projeto de prospecções arqueológicas da } \\
\text { igreja de São Lourenço dos Índios - Niterói/ } \\
\text { RJ. (C) }\end{array}$ & Najjar, R. \& col. \\
\hline & & $\begin{array}{l}\text { Arqueologia da Fazenda da Mandioca, Rio de } \\
\text { Janeiro, século XIX: o olhar da arquitetura. (C) }\end{array}$ & Vasconcellos, L.P.S. \\
\hline & & $\begin{array}{l}\text { Arqueologia em um casarão oitocentista da } \\
\text { antiga Vila do Príncipe-Serro/MG }\end{array}$ & $\begin{array}{l}\text { Baeta, A.M.; Camargo, } \\
\text { P.M.; Lima, S.J.F.S. \& de } \\
\text { Miranda, M.C.S. }\end{array}$ \\
\hline
\end{tabular}




\section{Referências bibliográficas}

\section{ANDRADE LIMA, T}

1993 Arqueologia Histórica no Brasil: balanço bibliográfico (1960-1991). Anais do Museu Paulista, História e Cultura Material (Nova série), São Paulo, 1: 225-262.

1996 Humores e Odores: ordem corporal e ordem social no Rio de Janeiro. Manguinhos -

História, Ciência e Saúde, Rio de Janeiro, 2 (3): 3-62.

1997 Chá e simpatia: uma estratégia de gênero no Rio de Janeiro Oitocentista. Anais do Museu Paulista, História e Cultura Material (Nova Série), São Paulo, 5: 93-129.

2000 Teoria e Método na Arqueologia Brasileira: avaliação e perspectivas. S. Mendonça de Souza (Ed.) Anais do IX Congresso da Sociedade de Arqueologia Brasileira. Versão eletrônica.

2002 O papel da arqueologia histórica no mundo globalizado. A. Zarankin; M.X. Senatore (Eds.) Arqueologia da Sociedade Moderna na América do Sul. Cultura Material, Discursos e Práticas. Buenos Aires, Ediciones del Tridente: 117-127.

BARBOSA, $\mathrm{M}$

2001 Os instrumentos científicos e a noção de cultura material. Simpósio Internacional Ciência e Tecnologia com Cultura e Desenvolvimento I. Resumos. São Paulo: 52.

BARBOSA, M.; GASPAR, M.D.

1998 Bibliografia brasileira sobre pescadores, coletores e caçadores. Publicações Avulsas

BARRETO, C do Museu Nacional, Rio de Janeiro: 56.

1999 Arqueologia Brasileira: uma perspectiva histórica e comparada. Revista do Museu de Arqueologia e Etnologia (Anais da I reunião Internacional de Teoria Arqueológica na América do Sul). São Paulo, Suplemento 3: 201-212.

2000 A construção de um passado pré-colonial: uma breve história da arqueologia do Brasil. Dossiê Antes de Cabral: Arqueologia Brasileira I, Revista da USP, São Paulo, 44: 32-51.

BOURDIEU, $P$.

1983 O campo científico. R. Ortiz (Ed.) Pierre Bourdieu, Textos. Coleção Grandes Cientistas Sociais: 122-155.

CHMYZ, I.

1976 Terminologia Arqueológica Brasileira para a Cerâmica. Cadernos de Arqueologia, Curitiba, l(1): 119- 147

DANIEL, G

1967 Historia de la Arqueologia. Madrid: Alianza Editorial.

FARIA,L.C.

1989 Domínios e Fronteiras do Saber: A Identidade da Arqueologia. IV Reunião Científica da Sociedade de Arqueologia Brasileira, Santos. M.C.M. Scatamacchia; M.I.D.A. Fleming (Eds.) Dédalo, pub. avulsa 1. São Paulo: 26-39.

FISH, S.; DE BLASIS, P.; GASPAR, M.D.; FISH, P.

2000 Eventos incrementais na construção de sambaquis, litoral sul de Santa Catarina. Revista do Museu de Arqueologia e Etnologia, São Paulo, 10: 69-87.

FUNARI, P.P.

1989 Brazilian archaeology and world archaeology: Some remarks. World Archaeological Bulletin, 3: 60-68.

1996 A Arqueologia de Palmares - sua contribuição para o conhecimento da História da cultura afro-brasileira. J.J. Reis; F. Gomes (Eds.) Liberdade por um fio. São Paulo, Cia das Letras: 26-51.

1991 A arqueologia e a cultura africana nas Américas, Estudos Ibero-Americanos, 17:61-71.

2000 Contribuições da arqueologia para a interpretação do Quilombo dos Palmares. Anais da IX Reunião da Sociedade de Arqueologia Brasileira, Rio de Janeiro, meio eletrônico. GASPAR, M.D.

1996 Datações, construção de sambaqui e identidade social dos Pescadores, Coletores e Caçadores. Anais da VIII Reunião da Sociedade de Arqueologia Brasileira, Porto Alegre: 377-398.

GASPAR, M.D.; FISH, P.; SCHELLL-YBERT, R.; FIGUTI, L.; KNEIP, A.; RIBEIRO, L.B.; FARIAS, D.S.E.; AFONSO, A.; KARL, R.J.; EGGERS, S.; FISH S.K.; DE BLASIS, P.

2002 Padrão de assentamento e formação de sambaquis: arqueologia e preservação em Santa Catarina. Revista de Arqueologia, IPHAN, Santa Catarina: 57-62.

HODDER, I.A.

1992 Theory and practice in archaeology. Routledge, Londres: 285.

KARL, R.

2000 The Relative Chronology of Cultural Episodes at the Coastal Sambaqui, Jabuticabeira II, in Santa Catarina, Brazil. 85 p., 13 il. Dissertação de Mestrado, Tucson, Universidade do Arizona.

KERN,A.A.

1994 Utopias e missões jesuíticas. Porto Alegre. Editora da Universidade/UFRGS. 96p.

1998 Pesquisas Arqueológicas e Históricas nas Missões Jesuítico-Guaranis (1985-1995). A.A Kern (Ed.) A Arqueologia Histórica Missioneira. Porto Alegre, EDIPUCRS: 11-64. ORSER JR, C.

1992 Introdução à Arqueologia Histórica. Belo Horizonte: Oficina de Livros. 143 p.

PROUS, A.

1991 Arqueologia Brasileira. Brasília: UNB. 111 p. 


\section{MCINTOSH, R.J.}

1996 History of Archaeology. M.B. Fagan; C. Beck et al. (Eds.) The Oxford Companion to Archaeology. New York, Oxford University Press: $280-285$.

MEGGERS, B.; EVANS, C.

1895 A utilização de sequiências cerâmicas seriadas para inferir comportamento social. Boletim Série Ensaios do Instituto de Arqueologia Brasileira, Rio de Janeiro: 1-30.

MENDONÇA DE SOUZA, A.

1991 História da Arqueologia Brasileira. Pesquisas, São Leopoldo, Antropologia 46. 157 p.

MENESES, U.B.

1983a Arqueologia Industrial: avaliação e perspectiva. Eurípedes Simões de Paula, São Paulo: 221-230.

1983b A cultura material no estudo das sociedades antigas. Revista de História, São Paulo, 15 (nova série): 103-112.

mimeo Tradução do artigo La "New Archaeology":
L'Archeologia como scienza sociale. in Dialoghi di Archeologia, 3s, Ano 1, 1. Ed Quasar.

RATHJE, W.

1996 Waste Management. M.B. Fagan; C. Beck et al. (Eds.) The Oxford Companion to Archaeology. New York, Oxford University Press: 744-745.

ROBRAHN-GONZÁLEZ,E.

2000 Arqueologia em perpectiva: 150 anos de prática e reflexão no estudo de nosso passado. Dossiê Antes de Cabral: arqueologia brasileira I, Revista da USP, São Paulo,44: 10-31.

ZANETTINI, P.E.

1996 Revisiting the war of the end of the world. 61st Annual Meeting of Society for American Archaeology. New Orleans, Resumos: 290.

WILLEY, GR.; PHILLIPS, P.

1955 Method and Theory in American Archaeology II: historical-developmental interpretations. American Anthropologist, 7: 723-819.

Recebido para publicação em 20 de dezembro de 2003. 